\title{
Poverty alleviation research in rural China: Three decades and counting
}

\author{
X.J. Jay Luo ${ }^{\dagger \ddagger \xi}$
}

This draft: Sep 22, 2019

\begin{abstract}
Poverty alleviation is a hallmark of post-revolution Chinese policymaking. Since 1978, the Communist Party of China (CPC) has implemented successive waves of poverty alleviation policies whose effects have become the focus of an ever-increasing body of academic literature. This paper reviews the diverse but limited literature that evaluates the impact of the CPC's rural poverty reduction programs through four major channels, namely fiscal investment programs, social safety nets, rural governance on the village-, county- and provincial level, and the relocation of rural populations from destitute regions. This paper aims to synthesize results and evaluate whether and to what extent these poverty alleviation programs have had distinct positive or negative impacts on regional development outcomes. Furthermore, I highlight contradictions in empirical findings to motivate the discussion about contextual importance when designing and implementing future rural poverty alleviation programs. Finally, I suggest that an exhaustive and critical appraisal of the empirical strategies used within the reviewed literature would further the development and application of more accurate and informative methodologies.
\end{abstract}

Keywords: Poverty alleviation, poverty analysis, depressed areas, welfare, regional policy

${ }^{\dagger}$ University of British Columbia, 2329 West Mall, Vancouver, BC V6T 1 Z4

$\ddagger$ St. George’s School, 4175 W 29th Ave, Vancouver, BC V6S 1V1, Canada

$\xi$ Corresponding author: jayluo215@gmail.com

* Declarations of interest: none 


\section{Introduction}

Since Deng Xiaoping's monumental market reforms in 1978, 700 million Chinese people have been lifted out of absolute poverty, accounting for $70 \%$ of poverty reduction worldwide (Error! Bookmark not defined.). In 2013, General Secretary Xi Jinping set the ambitious goal of lifting all 1.4 billion people out of destitution by the end of 2020, 10 years ahead of the United Nation's goal of eradicating poverty worldwide by 2030 (Wescott and Wang, 2019). By the end of 2018, the 832 poorest counties have already been reduced by at least 430, and at least 100,000 villages have exited extreme poverty (South China Morning Post, 2018). The $13^{\text {th }}$ Five-Year Plan (2016-2020) has the stated mission to lift 30 million people out of poverty through industrialization and investment, 10 million through employment opportunities, 10 million through ex situ resettlement, and 20 million through social security programs (Central Committee of the Communist Party of China, 2016; Zuo, 2019).

Despite the CPC's remarkable progress in poverty alleviation, the nature of rural poverty and the interplay of its causal factors have confounded scholars for decades. The first attempt to empirically document rural poverty ${ }^{1}$ was undertaken by Travers and Ma (1994), who investigated whether agricultural intensification and investment was effective in raising peasant incomes. Since then, rural poverty measurement in the literature has evolved from single-dimensional - that is, purely income-based-to multidimensional ${ }^{2}$, which takes into account social deprivations, the lack of human capital, and vulnerability to enter poverty. However, the integration of multiple poverty indicators is difficult, as empirically measuring many of these holistic indicators, with any degree of precision or consistency, remains challenging. While scholars have come to the consensus that a numeric cut-off line

\footnotetext{
1 There may have been earlier attempts to document poverty (especially in the Chinese literature), but those articles were excluded from the review for reasons described in the methodology section. ${ }^{2}$ Especially interesting is that the etymology of the Chinese word for poverty (pin kun 贫困) already implies the multidimensionality of poverty in China. Poor (pin 贫) is defined as "little income," while predicament (kun 困) is defined as a being entangled in a painful state of social captivity or environment. See Wang et al. (2016).
} 
is an oversimplified model of defining absolute poverty ${ }^{3}$, approaches have generally differed regarding poverty identification methods.

This paper is structured as follows: the first section gives a brief history of rural Chinese poverty alleviation. The second section outlines the review methodology used within this work. The third section discusses the evolution of research focus and experimental design of the literature. The fourth section discusses the key findings of this review. The fifth section concludes the paper.

\subsection{A brief history of poverty alleviation in rural China}

1949-1977 Economic development was stagnant in rural areas, whose populations were in a state of constant poverty during this period. Poverty alleviation policies were fruitless and misguided, focusing on the most basic physiological needs (food, clothing) of rural populations (Liu et al., 2018). This passive blood-transfusion form of poverty alleviation discouraged local economic growth, and transitions back into poverty were pervasive.

1978-1985 Deng Xiaoping's opening-up reforms led to gradual liberalizations in agriculture and business development. The household responsibility system inspired farmers to increase land output, which prompted a healthy increase in agricultural product prices. The formation of township and village enterprises (TVEs) laid the framework for rural economic structure. Poverty alleviation efforts became more comprehensive (e.g. fiscal investment in disparate and contiguous rural areas). Absolute poverty dropped 17.86 million

${ }^{3}$ The former official definition of poverty is based on the Chinese national poverty cut-off line of RMB 2300 (\$362.5) per capita annual income. Criticisms of the national poverty line - in addition to its dismissal of other poverty causes - are centered around its inflexibility. For example, the living standards of a person with a per capita annual income of RMB 2301 is virtually identical as one with a per capita annual income of RMB 2299. The cut-off is also criticized for being set too low in relation to the international standard. Using a 10-year panel data set from three provinces, Glauben et al. (2011) demonstrated that while only $4 \%$ of the households in lived five or more years in poverty according to the national poverty line, the portion increases to almost $40 \%$ when remeasured using the international poverty line (Glauben et al., 2011). 
people annually, and individuals unable to meet their basic needs dropped from $30 \%$ to $15 \%$ of the rural population during this period (Hu et al., 2005).

1986-1993 The rural economy sustained its economic growth, but inequalities emerged between eastern coastal cities and midwestern contiguous poverty areas. In 1986, the CPC established the State Council Leading Group on Poverty Alleviation and Development (LGOPAD 国务院扶贫开发领导小组). The establishment of this administration marked the first state-led poverty alleviation program in China.

1994-2000 This phase of poverty alleviation is characterized by the National 8-7 Plan, which aimed to resolve food and clothing problems of 80 million poor in midwestern mountainous regions. $82 \%$ of the 592 national poverty counties (an increase of 261 from the previous period) was concentrated in midwestern areas. The targets of the 8-7 Plan was achieved in 2000 - one year ahead of its planned completion date-and led to a 48-million decrease in rural poverty population in China. The 8-7 Plan marked a turning point in Chinese poverty alleviation policy as it had clear objectives, solutions, and duration (Liu et al., 2018).

2001-2013 ${ }^{4}$ Since the drafting of the "Outline for Development-Oriented Poverty Reduction for China's Rural Area" in 2001, rural China experienced over a decade of village-centric poverty reduction (Yan, 2016; Liu et al., 2018). Whole-village advancement measures such as rural infrastructure development and community-based development paved the way for more region-specific poverty alleviation, a precursor to the era of targeted poverty alleviation (2014-present). The tax-for-fee reforms (shuifei gaige 税费改革) in 2001 reduced agricultural tax burden for farmers; only five years later in 2006 did the CPC eliminate the two-thousand-year-old agricultural surcharge. In 2003, the new-type rural cooperative healthcare system (NRCHS) was designed to counteract poverty incidence caused by illness. The healthcare relief policies in 2004 provided "destitute" households with

\footnotetext{
${ }^{4}$ Other scholars categorize time periods differently. Liu et al. (2018) uses the period 2001-2012. Yan (2016) uses the period 2001-2010. 2013 was chosen as the end date in this paper because of the initiation to targeted poverty alleviation, which marked a turning point in the mechanism of the poverty alleviation program.
} 
"five welfare guarantees", benefitting 3.04 million deprived population in rural villages. By the end of 2010, China had lifted 58.26 million out of poverty and became the first nation to achieve the UN Millennium Development target of halving the poverty population.

2014-2020 Since 2013, China has implemented the 'targeted' poverty alleviation strategy (jingzhun fupin 精准扶贫). In 2013, the State Council released “Opinions on Promoting Rural Poverty Alleviation through Innovation Mechanisms," a programmatic document that stresses the need for an appropriate identification process for poverty alleviation. The document requires local governments to generate electronic reports for individual households, detailing the causes and circumstances of their poverty. In June 2015, Chairman Xi Jinping ratified the targeted poverty alleviation plan and positioned it at the forefront of Chinese poverty alleviation policy.

\section{Review Methodology}

Here I provide a brief overview of the methodology used to review the empirical works included in this review.

The quasi-systematic review of empirical methods and data. Original, peerreviewed research articles were selected from Elsevier, JSTOR, and SSRN. Publication dates were divided into time periods (1990-2000, 2001-2010, and 2011-2019) as they correspond to major poverty alleviation policies as well as shifts in the focus, methodology, and findings in the literature. The literature reviewed in this work focuses on poverty alleviation programs in $\mathrm{rural}^{5}$, rather than urban China because of its significantly higher poverty incidence, persistence and severity, and the rural-centricity of government policies. I omit research

\footnotetext{
${ }^{5}$ The characteristics that constitute an area as rural is poorly defined in China since 1) the CPC has provided multiple definitions of a "rural population" (see Martin, M. F. (1992). Defining China's Rural Population. The China Quarterly, (130), 392-401. Retrieved from JSTOR.) and 2) urban areas can grow by annexing parts of bordering rural areas (see Moreno, E. L. (2017, September 5). Concepts, definitions and data sources for the study of urbanization: The 2030 Agenda for Sustainable Development. Retrieved from https://www.un.org/en/development/desa/population/events/pdf/expert/27/papers/II/paperMoreno-final.pdf); however, that growth is unlikely to affect broad patterns of rural poverty.
} 
articles analyzing poverty alleviation perspectives on ecology, biodiversity, energy use, and tourism as environmental aspects of poverty bear little relevance to the canonical channels of poverty alleviation. Each study in this review was evaluated based on the components of its experimental design (geographical scope, time frame, sample source, sample size, dependent variables).

Search methodology. I use Elsevier, JSTOR, and Google Scholar as primary search engines. Restrictions were placed on the date of publication (1990-2000; 2001-2010; 20112019), the repository (restricted to Elsevier, JSTOR and SSRN), and topic (studies in other developing nations were rejected). The authors must have used a clear empirical approach to analyze the effects of poverty alleviation policy in rural China. The research articles were catalogued according to the policies they analyze ${ }^{6}$.

\section{Examples of search phrases:}

- China poverty alleviation "[insert methodology here]" -urban.

- Rural microfinance China poverty Elsevier - Vietnam -Thailand

- Poverty alleviation resettlement rural China JSTOR

There are important points to be discussed about this methodology. First, this work should not be considered a meta-analysis, as a formal search algorithm was not used ${ }^{7}$, and there has been no attempt to create standardized impact estimates. Secondly, I acknowledge the exclusion of Chinese research, or other international research, that may not be included in the repositories. I therefore acknowledge that there may exist publication and inclusion bias resulting from the specific sources used for this review.

\section{Experimental design in the literature}

\subsection{Research questions}

\footnotetext{
${ }^{6}$ In this review: fiscal investment, social support, resettlement, and governance mechanisms.

7 The relatively limited literature in poverty alleviation research in rural China and the dissimilarity of geographic regions rendered an algorithm unnecessary. Alterations in word order in the searches generally did not affect search results.
} 
Scholars have posed research questions that have both evolved and remained the same with the progression of poverty alleviation policy. While new research focuses have emerged, core concerns such as the optimization of quantitative methods to more accurately measure poverty have remained. Travers and Ma (1994) investigated the effects of agricultural investment on rural poverty, consistent with the primary objective of the eight Five-Year Plan (1991-1995) of direct irrigation investment. The first definitions of transient and chronic poverty were provided by Jalan and Ravallion (1998), followed up by another study that probed the causes of transient poverty, as well as the implications of the interplay between transient and chronic poverty for measurements of overall poverty (Jalan and Ravallion, 1999). These pioneer studies allowed for more specific analyses in the mutual exclusivity of transient and chronic poverty (Jalan and Ravallion 2000, 2001; Mcculloch and Calandrino, 2003; Duclos et al., 2010), and, on a broader level, introduced the inherent complexity of rural poverty - perhaps foreshadowing the need for multidimensional approaches, a topic explored by later works - and how effective policy should adapt to rural poverty's unpredictable fluctuations.

A fundamental understanding of rural poverty has enabled scholars to scrutinize poverty alleviation policy in its distinct forms ${ }^{8}$. Hannum (2003) investigated how local community resources influence educational inequality, providing a reference for a twodecade study that incorporated multidimensional poverty measurement metrics to evaluate child poverty (Qi and Wu, 2015). Cheng (2006, 2007) examined the targeting efficacy of rural microfinance policy, leading the way for further investigation in the welfare outcomes of microfinance programs (Li et al., 2011; Turvey and Kong, 2010; You and Annim, 2014; Ding et al., 2018). Carrin et al. (1999) provided the first temporal evaluation of the Rural Cooperative Medical System in fourteen pilot counties, laying the framework for further analysis of distributive properties of healthcare policy in poverty alleviation (Yang et al., 2016; Chen et al., 2018). It was not until 2017 that the innerworkings of social poverty policy was elucidated, likely because of the difficulty of measuring social capital and the

\footnotetext{
${ }^{8}$ It should be noted, however, that there were not particular focuses on specific poverty alleviation programs until after 2010 .
} 
paucity of national or inter-regional data. The works of Ratigan (2017), Zhang et al. (2017), Golan et al. (2017), and Kakwani et al. (2017) analyzed regional differences in social welfare provision, the association between social relationships and the probability of living in poverty, and the effectiveness of the dibao program. In light of recent poverty resettlement efforts, Xue et al. (2013) inspected the mechanisms of voluntary ${ }^{9}$ poverty resettlement as Lo and Wang (2018) gauged the distributive properties and potential biases of such programs.

The efforts in the literature to characterize rural poverty in China, described above, points to the multifaceted nature of rural poverty. A breakthrough in poverty measurement came in 2007 when developmental economists Sabina Alkire and James Foster published a series of papers on multidimensional poverty that encapsulated - as the name suggests - the multiple causal factors of poverty. Yu (2013), Qi and Wu (2015), Wang and Wang (2016), Alkire and Wang (2018), and Shen et al. (2019) used this method to paint a more complete picture of multidimensional rural poverty in China (see Appendix A). It is likely that these multidimensional measurements will receive more attention in the future for their ability to capture previously underappreciated contributors to rural poverty.

\subsection{Sampling}

The geographical scope and (quasi-)experimental design of the research articles have generally remained comparable, which can be explained by the recurrence and persistence of poverty in the mid-west and northwestern regions over the past three decades. The time frames of the empirical literature are attuned to the dates of key policies such as the National 8-7 Plan (1994-2000). Therefore, it is of interest and more feasible to investigate clearly defined periods of poverty policy to gauge the effects thereof ${ }^{10}$.

\footnotetext{
9 The definition of "voluntary" versus that of "involuntary" poverty alleviation resettlement programs was a debated topic, with Wilmsen and Wang (2015) proposing that a people-centered approach, not volition is the driver of improved outcomes in PAR.

${ }^{10}$ Another reason that scholars are not able to extend the temporal scope of empirical research is the paucity of credible and accessible poverty statistics. These poverty data are rarely made public and require personal relations with local officials, which is also a determining factor of the effectiveness of qualitative research, explored more in the section on empirical methodologies.
} 
The limited sampling capacity of empirical research during the first phase (19902000) of poverty alleviation research can largely be derived from geographical heterogeneity and highly decentralized and county- and village-specific policy implementation. Policy implementation bears little similarity across counties, sometimes even within villages (Park and Wang, 2010). As a result, researchers often resorted to the analysis of two to three provinces with adequately comparable geographic and demographic characteristics with regards to poverty levels in these areas. The consequence of this compromise is a restricted sample size, which is often limited to county- or village-level populations. In addition, the data sources used during this period (1990-2000) were fairly homogenous among the studies, with 3 of 5 studies using data from the Rural Household Survey ${ }^{11}$ (RHS), with the exception of Chen and Ravallion (1996), who conducted face-to-face interviews with local officials. Jalan and Ravallion (2001) even opted to re-use survey data from studies done several years ago due to the scarcity of reliable data and of national-level surveys conducted by the government. Overall, there was little attempt to empirically measure and interpret rural poverty during this period.

With the maximum length of five years ${ }^{12}$, studies during the first phase were relatively uninformative about whether and how the central government should optimize policy options for distinct geographical regions. Observations from poverty measurement studies had been derived from national household surveys (e.g. Rural Household Survey (RHS)), which are cross-sectional, not longitudinal data. Cross-sectional data obtained at a single point in time do not provide any indication of the a priori or post priori conditions of poverty, thereby failing to capture fluctuations in poverty levels between the times of measurement. It was not until 1998 when Jalan and Ravallion (1998) addressed this by

\footnotetext{
11 The RHS began in 1955, presumably the oldest survey accessible. The credibility of the surveys, however, was questionable and access to the results were largely restricted until the early 1990s. 12 Jalan and Ravallion $(1996,1998,2001)$ used the same dataset likely due to data unavailability from other surveys.
} 
constructing a new panel data set was from the RHS ${ }^{13}$ done by China's State Statistical Bureau (SSB).

A clear upward trend in sample size and data variety began in the late-2000s. Montalvo and Ravallion (2009), using a sub-national panel dataset constructed by the authors and China's National and Provincial Bureaus of Statistics, evaluated rural China's economic growth from 1983 to 2001, re-defining the "longitudinal study" in rural Chinese poverty alleviation research. Duclos et al. (2010) used survey data conducted annually by China's Research Center for Rural Economy (RCRE) to measure long-term changes in transient and chronic poverty incidence from 1986 to 2002, followed by many others that used the growing wealth of rural poverty data provided by all levels of Chinese administration (Appendix A).

\section{Findings and Discussion}

Drawing on the diverse repertoire of literature in Chinese poverty alleviation, I argue that there is no singular, primary cause for rural poverty ${ }^{14}$ and that whether the CPC's poverty alleviation programs are effective is not so clear-cut. All the evidence points to the fact that Chinese rural poverty is a concoction of geographic location and natural conditions, local governance, and the array of stochastic indicators of transient and chronic poverty.

\footnotetext{
${ }^{13}$ The authors note that the RHS has been a well-designed budget survey of a random sample of households drawn from a sample frame spanning rural China (including small- medium towns), with unusual effort made to reduce non-sampling errors. Sampled households fill in a diary on daily expenditures and are visited on average every two weeks by an interviewer to check on the diaries and collect other data. There is also an elaborate system of cross-checking at the local level. The consumption data obtained from such an intensive survey process are almost certainly more reliable than those obtained by the far more common cross-sectional surveys in which the consumption data are based on recall at a single interview or possibly with one follow-up interview. For a six-year period 1985-1990, the survey was also longitudinal, as it sampled the same households over time. 14 Though there certainly are primary causes of poverty for inhabitants in specific contexts (e.g. for the poor people living in mountainous areas, natural factors and lack of infrastructure is the main contributor of poverty).
} 
Several generalizations can be made. Expectedly, investment in agriculture has remained effective in reducing poverty (Travers and Ma, 1994; Montalvo and Ravallion, 2009; You, 2014; Imai and You, 2014), especially in the poorest areas where there are no readily available external sources of employment. Investment in education has also been shown to be successful in reducing poverty vulnerability (Hannum, 2003; Goh et al., 2009; Glauben et al., 2011; Imai and You, 2014; Lü, 2015; Ratigan, 2017; Ren et al., 2017; Alkire and Shen, 2018), although the study areas are generally limited to several provinces and may reflect regional peculiarities ${ }^{15}$ rather than national-level trends. It seems that the programs that are commonly associated with international poverty alleviation generally hold true for rural China despite drastic demographic and spatial differences. That said, inequalities remain and whether and how they will be addressed is a moot point.

Perhaps the most important finding of this review is that studies that analyze the same policy can produce different, even opposite, findings. I argue that, ceteris paribus ${ }^{16}$, these differences can primarily be attributed to spatial heterogeneity ${ }^{17}$ and that regional differences in sampling in studies are not negligible. Whereas Ravallion and Chen (2005) find that microfinance programs have little or no impact on permanent income, Li et al. (2011), You and Annim (2014) and Ding et al. (2018) all find significant positive impacts stemming from these programs. A comparison of geographic regions of the studies reveals that the study done by Ravallion and Chen (2005) was conducted in southwestern provinces, whereas the other three studies focus almost exclusively on central provinces. Whereas Xue et al. (2013) find positive effects of poverty alleviation resettlement (PAR programs) on economic opportunities and social welfare in Linfen Prefecture in Shanxi Province, Lo and Wang (2018) find inconsistencies in implementation in Ji County ${ }^{18}$, a mere

\footnotetext{
${ }^{15}$ Goh et al. (2009) is an exception (see Appendix A).

${ }^{16}$ I acknowledge that there may be other variables driving these differences (e.g. differences in methodology, time frame); however, only geographic heterogeneity has been concretely shown to be involved in differences in poverty severity and type.

${ }^{17}$ I refer to not only geographic and natural characteristics but also the variation in the attention local governments pay to individual counties or villages (i.e. differences in local governance).

18 This finding is, however, consistent with the elite capture observed by Rogers (2014) in a qualitative study done in four villages in Ji County.
} 
100 kilometers from Linfen Prefecture ${ }^{19}$; Liu et al. (2018) emphasize distinct program outcomes between different relocation regions in a study done in Ankang Prefecture. Yang et al. (2016) finds coverage issues in the New Cooperative Medical Scheme (NCMS) in the inland Shaanxi Province, whereas Chen et al. (2018) find improved service accessibility in the eastern coastal Zhejiang Province. The pattern of provincial and regional exceptions plays itself out in all channels of poverty alleviation-grave targeting errors or questionable local accountability cannot and should not be generalized, and the failure of an investment program on one region does not mean that it will have the same effect in another.

But what might be driving the regional differences? The villages investigated by Ravallion and Chen (2005), while unnamed, show features characteristic of non-agricultural, mountainous regions ${ }^{20}$ such as the lack of electricity, relatively long distances to the nearest market, village county town, or township, and poor transport infrastructure. The Southwest Poverty Reduction Project (SWPRP), which was the program analyzed in the study, attempted to generate income through traditional poor-village investment initiatives that primarily targets agriculture and rural infrastructure (43.05\% and $17.24 \%$ of total investment, respectively; Ravallion and Chen (2005)). In theory, these initiatives would account for much of the poverty - they certainly are causal factors of rural poverty, after all. In practice, however, this is not at all the case for these specific villages. It may well be that what they need most is actually what the program emphasizes least: health, education, and institution building $(5.37 \%, 8.60 \%$, and $1.69 \%$ of total investment, respectively; Ravallion and Chen (2005)), all of which are essential for sustainable poverty reduction.

Given that there appears to be a positive association between variability in geographic features and multidimensional poverty, it seems reasonable to compare the levels of multidimensional poverty between the southwestern villages ${ }^{21}$ in Ravallion and Chen (2005) with the provinces in the central regions of Li et al. (2011), You and Annim (2014) and

\footnotetext{
19 The reason for this difference is unclear. Studies have not yet examined regional differences in program implementation at the prefecture scale.

${ }^{20}$ These conclusions are validated by regression outputs in the paper.

${ }^{21}$ To account for this uncertainty, I will use the MPIs from Yunnan and Sichuan, two southwestern provinces associated with high rural poverty incidence and persistence, as placeholders.
} 
Ding et al. (2018). A comparison using available data generated in Shen et al. (2019), which extracted multidimensional poverty indices $^{22}$ (MPIs) from the CFPS from 2010 through 2014, reveals that Sichuan and Yunnan province have higher (around three-fold) MPI weightings than Jilin, Henan, and Hubei province. Among the individual dimensions measured by the MPI, Sichuan and Shaanxi are significantly more deprived in child education, nutrition, electric power, drinking water, and cooking fuel, causes and symptoms of poverty that have troubled southwestern areas for decades. Given that these studies evaluated the impacts of microfinance and investment programs, it is likely that these programs were more effective in Jilin, Henan, and Hubei because there simply was less "dimensions" of poverty (i.e. income deprivation as the primary causal factor) to account for than in southwestern regions that are enriched in multidimensional poverty (i.e. income deprivation as only one of the many causal factors, all of which have effects are relatively less severe but together manifest an aggressive synergistic ${ }^{23}$ effect).

The fact that the literature can be identified with distinct aspects of rural poverty, among them fiscal, social and health poverty, signifies that poverty alleviation programs are not yet inclusive enough to confront all dimensions of poverty. That said, PAR programs do hold some promise as they have been shown, at least regionally, to dramatically improve living and economic conditions for those that chose to re-locate. It is expected that PAR programs will do even more to reduce the financial burden on the relocated by providing more affordable transportation services, carry out community-based programs to foster social capital, assist the relocated in their search job searches by providing training in specific skills, and, most importantly, ensuring that the non-movers do not continue to suffer from endemic chronic poverty.

\footnotetext{
${ }^{22}$ Defined as \% incidence of deprivation.

${ }^{23}$ I argue that the pernicious effects of each multidimensional indicator (e.g. education, nutrition, electric power, drinking water, and cooking fuel) are synergistic, not additive, because each seems to reinforce the others, eventually creating a vicious circle. This could also explain the daunting difficulty of tackling multiple poverty indicators through implementing only one antipoverty program.
} 
The policy implications of these findings are far-reaching: the specificity to which policies may be required to adapt will need to be on the village- or even on the householdlevel. Future attempts to create more targeted poverty alleviation programs should aim to ensure that not one of the millions of people who exit poverty relapses for any reason, be it a transient income shock, adverse natural conditions, or poor local governance. The "eradication" of poverty should therefore be defined as the elimination of every possible root cause of poverty through painstakingly specific programs and the ridding of the whack-amole approach to policy implementation that still plagues some of the poorest rural areas. The sources of poverty that we know of ${ }^{24}$ may be incredibly difficult to control for given that there are hundreds of counties and thousands of villages in poverty at any given time. Because of the context-specific nature of rural poverty, a more holistic and multidimensional approach should be used to evaluate poverty not only in rural China but also internationally. Despite clear evidence that certain aspects of the CPC's plan can and must be improved, we must refrain from making brazen conclusions about the plan's validity or effectiveness.

It is important to be cognizant of the inherent noise involved in rural Chinese poverty alleviation research. This paper assumes that the data sources are free of error and bias ${ }^{25}$ and that empirical strategies are optimal for the context of a specific province, county, or village. We also lack a firm grip on the precise mechanisms by which poverty alleviation is carried out in the poorest of the poor areas, and it is certainly possible that exogenous influences such as ulterior political motives distort survey data. An in-depth survey of empirical strategies and the relationship between the context of rural poverty and empirical methods will be a crucial step in our quantitative understanding of poverty and development in rural China. I have provided an overview of all the empirical methods

\footnotetext{
24 These conclusions are made on the assumption that scholars have already "decoded" all the possible sources of poverty. It may well be that new or unknown sources of poverty will surface as time progresses and as more novel poverty alleviation approaches such as e-commerce and tourism become more widespread.

${ }^{25}$ This is highly unlikely, especially when nationwide questionnaires are designed for millions of poor people from geographically distinct regions.
} 
researchers have used to date (Appendix B) and anticipate that these methods will continue to be fine-tuned to match the dynamics of Chinese rural poverty.

\section{Conclusion}

To the author's knowledge, this is the first quasi-systematic review of the rural Chinese poverty alleviation literature. It is reasonable to conclude that Chinese poverty alleviation policy is partitioned into periods of gradual and intense focus, as is the research that seeks to better understand rural poverty dynamics. As poverty alleviation shifted from being more material-centric to region- and household-specific, so did the literature.

As of April 2019, there are still approximately 373.1 million people living in extreme poverty (World Bank, 2019) ${ }^{26}$ in China. Eradicating poverty by 2020 remains a daunting task despite the extensive scale of poverty alleviation efforts. It is likely that rural poverty and its intricacies will continue to pose challenges for the CPC even after supposed 'eradication'. ${ }^{27}$ The CPC nevertheless appears to be willing to devote as much resource as needed into this unprecedented effort for as long as rural poverty persists in China.

\section{Acknowledgements}

The author would like to thank Professor Wei Cui and Avery Maloney for their valuable comments and openness to discussion during the course of writing.

\footnotetext{
${ }^{26}$ While the UN rightly defines 'extreme' as earning less than $\$ 5.50$ a day, the literature has recognized that poverty is not entirely income-dependent (although it plays a large role in poverty) and there may be, especially in a country as large and complex as China, millions suffering from poverty with other inadequacies, among them social poverty, education deprivation and the inaccessibility of healthcare. This situation, again, stresses the need for more holistic measurements of poverty that encompass multiple possible sources of rural poverty.

${ }^{27}$ The reviewed literature has made a strong case for more optimized policy for different types of poverty (e.g. transient or chronic) in different regions of China.
} 


\section{Appendix A: Study design}

\begin{tabular}{|c|c|c|c|c|c|c|}
\hline Authors of study & Geographical scope & $\begin{array}{l}\text { Time } \\
\text { frame }\end{array}$ & Data source & Research question(s) & & Key findings \\
\hline $\begin{array}{r}\text { Travers and Ma } \\
\text { (1994) }\end{array}$ & 12 provinces $^{28}$ & $1980-1987$ & $\begin{array}{l}\text { China's County } \\
\text { Level Rural } \\
\text { Economic Statistical } \\
\text { Abstract }\end{array}$ & $\begin{array}{l}\text { Can agricultural } \\
\text { intensification and } \\
\text { investment raise peasant } \\
\text { incomes in poor areas? }\end{array}$ & & $\begin{array}{l}\text { Increased use of machinery and } \\
\text { fertilizer offers some potential for } \\
\text { increasing peasant income in rural } \\
\text { areas. } \\
\text { Investment in irrigation in poor } \\
\text { regions would only increase net } \\
\text { peasant incomes if government } \\
\text { subsidies compensate for at least a } \\
\text { third of the costs of the projects. }\end{array}$ \\
\hline $\begin{array}{r}\text { Chen and } \\
\text { Ravallion (1996) }\end{array}$ & $\begin{array}{l}\text { Guangxi, Yunnan, } \\
\text { Guizhou, and } \\
\text { Guangdong }\end{array}$ & $\begin{array}{l}1985- \\
1990^{29}\end{array}$ & $\begin{array}{l}\text { Rural Household } \\
\text { Survey (RHS); in- } \\
\text { person interviews } \\
\text { with county officials }\end{array}$ & $\begin{array}{l}\text { (1) How can we better } \\
\text { understand and validate } \\
\text { poverty rates from } \\
\text { existing data (i.e. how } \\
\text { can we improve data- } \\
\text { collecting methods)? (2) } \\
\text { How can we corroborate } \\
\text { the concerns of } \\
\text { policymakers regarding } \\
\text { the effectiveness of the } \\
\text { policies in the 1980s? }\end{array}$ & - & $\begin{array}{l}\text { Poor distributional effects of policies } \\
\text { led to preferential growth in rural } \\
\text { areas in coastal regions. } \\
\text { Inland provinces experienced slower } \\
\text { growth. }\end{array}$ \\
\hline
\end{tabular}

${ }^{28}$ Heilongjiang, Neimenggu, Hebei, Henan and Shanxi are in North and North East China; Sichuan, Hubei, Jiangxi, and Jiangsu.

${ }^{29}$ The authors note that 1984 data was unavailable because it was a trial period and the data produced were unreliable. 


\begin{tabular}{|c|c|c|c|c|c|c|}
\hline $\begin{array}{r}\text { Jalan and } \\
\text { Ravallion (1998) }\end{array}$ & $\begin{array}{l}\text { Four contiguous } \\
\text { provinces in southern } \\
\text { China, namely } \\
\text { Guangxi, Yunnan, } \\
\text { Guizhou and } \\
\text { Guangdong }\end{array}$ & $1985-1990$ & $\begin{array}{l}\text { Rural Household } \\
\text { Survey (RHS) }\end{array}$ & $\begin{array}{l}\text { How can we better } \\
\text { understand and measure } \\
\text { the extent of poverty } \\
\text { through different time } \\
\text { scales }^{30} \text { ? }\end{array}$ & & $\begin{array}{l}\text { Consumption variability is responsible } \\
\text { for much of the observed poverty and } \\
\text { possibly poses a severe barrier on } \\
\text { efforts to combat chronic poverty. }\end{array}$ \\
\hline $\begin{array}{r}\text { Jalan and } \\
\text { Ravallion (1999) }\end{array}$ & $\begin{array}{l}\text { Guangxi, Yunnan, } \\
\text { Guizhou and } \\
\text { Guangdong }\end{array}$ & $1985-1990$ & RHS & $\begin{array}{l}\text { To what extent are the } \\
\text { needs of households in } \\
\text { poor rural economies } \\
\text { similar or different, and } \\
\text { does the existing } \\
\text { consumption insurance } \\
\text { work better for some } \\
\text { groups than others? }\end{array}$ & - & $\begin{array}{l}\text { There is ample evidence for the } \\
\text { existence of consumption insurance in } \\
\text { poor villages in southern China; } \\
\text { however, these programs work } \\
\text { noticeably less well for the poorest of } \\
\text { the poor. } \\
\text { There is evidence for inequitable } \\
\text { economic growth within poor rural } \\
\text { economies in Southern China. }\end{array}$ \\
\hline
\end{tabular}

30 The first definitions of transient and chronic poverty.

31 Tongxian and Pinggu (Beijing), Qidong and Xinghua (Jiangxu Province), Haining and Xiaoshan (Zhejiang Province), Xinmi and Wuzhi (Henan Province), Wuxue and Changyang (Hubei Province), Yongning and Lingwu (Ningxia Province) and Yongxiu and Yihuang (Jiangxi Province); early 1995, Tongxian County was replaced by Fangshan County of Beijing. 


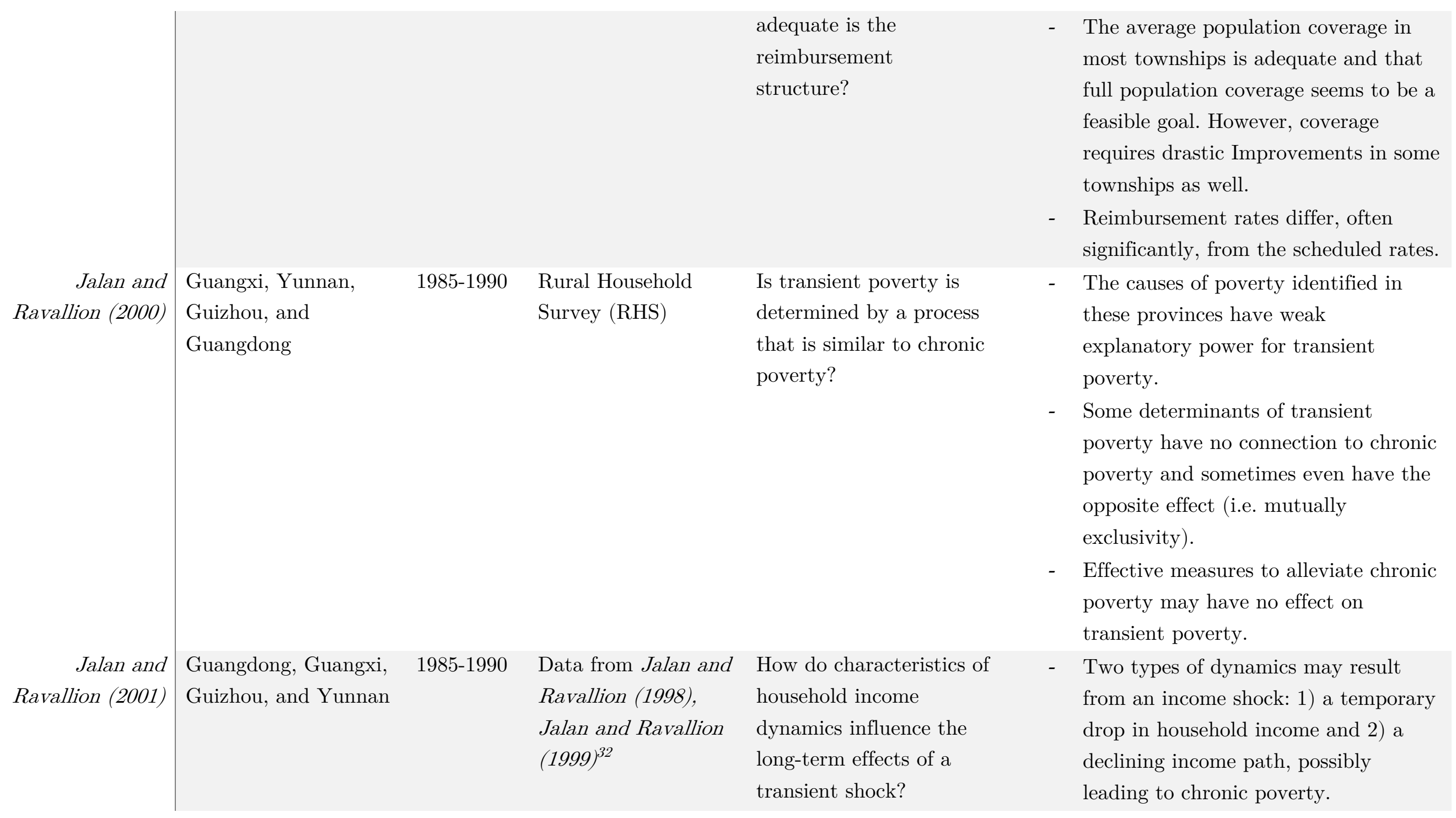

${ }^{32}$ While the authors base their paper off of past results, they approach the data with improvements in quantitative methods, outlined in the next section of this review. 


\begin{tabular}{|c|c|c|c|c|c|c|}
\hline Park et al. (2002) & $\begin{array}{l}592 \text { national poverty } \\
\text { counties }\end{array}$ & $\begin{array}{l}1981- \\
1995^{33}\end{array}$ & National panel data & $\begin{array}{l}\text { How effective is regional } \\
\text { targeting in alleviating } \\
\text { rural poverty? }\end{array}$ & - & $\begin{array}{l}\text { While the coverage of policies has } \\
\text { improved, political factors have } \\
\text { affected targeting and leakage has } \\
\text { increased. } \\
\text { The selection of 'poor' counties may } \\
\text { be politically biased. }\end{array}$ \\
\hline Hannum (2003) & Nationwide & 1992 & $\begin{array}{l}\text { Rural component of } \\
\text { the National Sample } \\
\text { Survey of the } \\
\text { Situation of Chinese } \\
\text { Children }\end{array}$ & $\begin{array}{l}\text { (1) How do local } \\
\text { community resources } \\
\text { influence educational } \\
\text { inequality? (2) In what } \\
\text { ways do village } \\
\text { characteristics affect } \\
\text { children? }\end{array}$ & - & $\begin{array}{l}\text { Village and household incomes and } \\
\text { village provision of junior high schools } \\
\text { impacted on children's enrollment } \\
\text { probabilities. } \\
\text { Village income effects did not change } \\
\text { with family income. i.e. the effect of } \\
\text { village income was additive. }\end{array}$ \\
\hline $\begin{array}{r}\text { Mcculloch and } \\
\text { Calandrino (2003) }\end{array}$ & Sichuan Province & 1991-1995 & $\begin{array}{l}\text { Household Survey } \\
\text { Division of the Rural } \\
\text { Survey Organization } \\
\text { in the National } \\
\text { Bureau Statistics } \\
\text { (NBS) }\end{array}$ & $\begin{array}{l}\text { How chronic is poverty } \\
\text { in China? }\end{array}$ & - & $\begin{array}{l}57 \% \text { of the households experience } \\
\text { transient poverty (one or more years } \\
\text { of poverty). } \\
\text { Geographic location has the most } \\
\text { significant impact on poverty } \\
\text { vulnerability }{ }^{34} \text { as well as chronic } \\
\text { poverty. } \\
\text { Household size is significantly related } \\
\text { to chronic poverty. }\end{array}$ \\
\hline $\begin{array}{r}\text { Ravallion and } \\
\text { Chen (2005) }\end{array}$ & $\begin{array}{l}20 \text { project counties, } \\
200 \text { villages in }\end{array}$ & $1996-2000$ & $\begin{array}{l}\text { Rural Household } \\
\text { Survey (RHS) }\end{array}$ & $\begin{array}{l}\text { What is the savings } \\
\text { behavior of beneficiaries }\end{array}$ & - & $\begin{array}{l}\text { A large share of the income gained } \\
\text { was saved by the participants in the } \\
\text { project over } 5 \text { years. }\end{array}$ \\
\hline
\end{tabular}

\footnotetext{
33 The panel data is broken down into the time periods 1981-1985, 1985-1989, 1989-1992, and 1992-1995

34 The authors stress the need for a more location-dependent targeting mechanism.
} 


\begin{tabular}{|c|c|c|c|c|c|}
\hline & $\begin{array}{l}\text { southwestern } \\
\text { provinces }\end{array}$ & & & $\begin{array}{l}\text { of a large poor-area } \\
\text { development project? }\end{array}$ & $\begin{array}{l}\text { - Despite an overall gain income, little } \\
\text { to no impact on consumption was } \\
\text { found upon comparing the first and } \\
\text { final years of the project. } \\
\text { - The project's effects on permanent } \\
\text { income are unknown. }\end{array}$ \\
\hline Cheng (2007) & $\begin{array}{l}\text { Aohan, Nanzhao, } \\
\text { Zhuoquan, Linxian } \\
\text { Counties of Chifeng } \\
\text { Prefecture }\end{array}$ & Mid-2005 & RHS & $\begin{array}{l}\text { (1) What factors affect } \\
\text { the household demand } \\
\text { for micro-loans in an } \\
\text { evolving economic } \\
\text { environment? } \\
\text { (2) How can we } \\
\text { understand the demand } \\
\text { of the poor for } \\
\text { microfinance from a } \\
\text { behavioral perspective? } \\
\text { (3) How effective and } \\
\text { far-reaching are } \\
\text { microfinance institutions } \\
\text { in targeting the poor? }\end{array}$ & $\begin{array}{l}\text { Microfinance projects in China failed } \\
\text { to target the poorest of the poor and } \\
\text { have not made a positive impact to } \\
\text { poverty reduction. } \\
\text { - The demand for micro-loans is } \\
\text { positively correlated to household } \\
\text { income, opportunities for off-farm } \\
\text { investment and the educational level } \\
\text { of borrowers. } \\
\text { - Wealthier (middle-income and above) } \\
\text { rural households are the key } \\
\text { beneficiaries of microfinance } \\
\text { institutions. } \\
\text { The institutions were effective in } \\
\text { reducing overall poverty despite the } \\
\text { targeting errors. }\end{array}$ \\
\hline $\begin{array}{l}\text { Montalvo and } \\
\text { avallion (2009) }\end{array}$ & $\begin{array}{l}\text { All } 23 \text { provinces }+3 \\
\text { municipalities }^{35}\end{array}$ & $1983-2001$ & $\begin{array}{l}\text { Sub-national panel } \\
\text { dataset constructed } \\
\text { by the authors and }\end{array}$ & $\begin{array}{l}\text { What role does economic } \\
\text { growth-which has been } \\
\text { highly uneven across }\end{array}$ & $\begin{array}{l}\text { - Agriculture has been the driving force } \\
\text { in poverty reduction, rather than }\end{array}$ \\
\hline
\end{tabular}

\footnotetext{
${ }^{35}$ Beijing, Tianjin, and Shanghai. The authors also note that Chongquing, a newly created municipality at the time of writing, offered limited amounts of data and was therefore not included in the empirical analysis.
} 


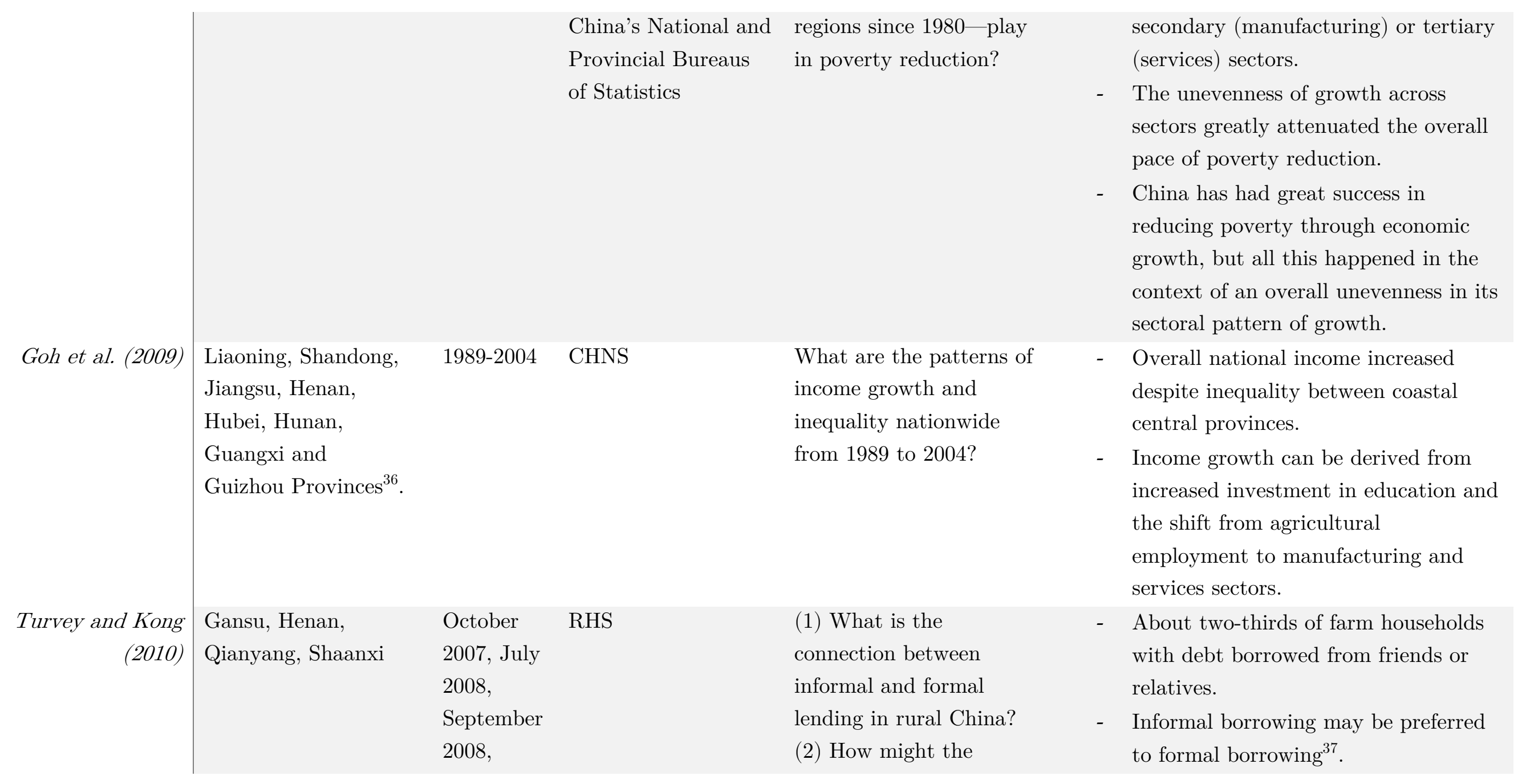

\footnotetext{
${ }^{36}$ The provinces were selected because they are regionally representative.

37 The authors point out that cultural factors and the role of trust is a key determinant of informal borrowing dynamics in rural China. To demonstrate this point, they compare informal borrowing preferences outcomes from this study with a study in four Indian districts and found that Chinese farmers, on average, is much more inclined to borrow from family and relatives compared to Indian farmers (see Kumar,
} 


\begin{tabular}{|c|c|c|c|c|c|c|}
\hline & & $\begin{array}{l}\text { October } \\
2008\end{array}$ & & $\begin{array}{l}\text { strength of informal } \\
\text { lending affect } \\
\text { microfinance? }\end{array}$ & & \\
\hline Duclos et al. (2010) & $\begin{array}{l}\text { Anhui, Gansu, } \\
\text { Guangdong, Henan, } \\
\text { Hunan, Jiangsu, Jilin, } \\
\text { Shanxi, and Sichuan }\end{array}$ & 1986-2002 & $\begin{array}{l}\text { Survey data } \\
\text { conducted annually } \\
\text { by China's Research } \\
\text { Center for Rural } \\
\text { Economy (RCRE) }\end{array}$ & $\begin{array}{l}\text { How can better } \\
\text { statistical and empirical } \\
\text { methods be employed to } \\
\text { more accurately measure } \\
\text { transient and chronic } \\
\text { poverty? }\end{array}$ & - & $\begin{array}{l}\text { Different poverty measurements yield } \\
\text { significantly different estimates of } \\
\text { chronic and transient poverty. }\end{array}$ \\
\hline $\begin{array}{r}\text { Park and Wang } \\
\text { (2010) }\end{array}$ & $\begin{array}{l}\text { Six unnamed } \\
\text { provinces }\end{array}$ & 2001-2004 & $\begin{array}{l}\text { A subset of the } \\
\text { National Bureau of } \\
\text { Statistics (NBS) } \\
\text { annual RHS }\end{array}$ & $\begin{array}{l}\text { How effective is } \\
\text { community-based } \\
\text { development (poor } \\
\text { village investment } \\
\text { program)? }\end{array}$ & & $\begin{array}{l}\text { The program generally increased both } \\
\text { governmental and village investments. } \\
\text { While the program did not increase } \\
\text { the income or consumption of poorer } \\
\text { households, it did increase the income } \\
\text { and consumption of richer households. } \\
\text { There is evidence that governance } \\
\text { matters in the distribution of program } \\
\text { benefits. Relative gains were greater } \\
\text { for richer households in villages with } \\
\text { more educated leaders, and higher } \\
\text { quality village committees delivered } \\
\text { greater benefits to both richer and } \\
\text { poorer households. }\end{array}$ \\
\hline
\end{tabular}

C. (2009) "Credit Rationing and The Economics Of Informal Lending: Theoretical Results and Econometric Inferences Using the Household Surveys From

China and India". Unpublished PhD Dissertation. Cornell University August 2009.) 
Zhejiang, Hubei,

Yunnan Provinces

1995-2004

Survey data

conducted annually

by China's Research

Center for Rural

Economy (RCRE)
What are the

determinants of longterm poverty and what is the duration dependence on the probability to leave poverty?

\section{Hubei Province}

What is the impact of microfinance programs on household welfare outcomes such as income and consumption in rural China?
- The majority of population seems to be only temporary poor.

- However, the probability to leave poverty for those who were poor is differently affected by poverty duration across provinces, ranging from no duration dependence in Zhejiang to highly significant duration dependence in Yunnan.

- The number of nonworking family members, education, and several village characteristics seem to be the most important covariates.

- Despite the general conclusion that poverty is a transitory phenomenon, poor Chinese provinces show a higher relevance of persistent poverty across all poverty thresholds. Thus, different policy measures are needed in order to well address these issues.

- Participating in microfinance programs helps improve households' welfare by raising household income and consumption.

- Total amounts of microfinance obtained by the households have a positive and significant impact on welfare outcomes, suggesting a 
Xue et al. (2013)

\section{Shanxi Province}

July-

August

2010, July

2012

Meng (2013) National poor counties of the 8-7 Plan

1981-1995 Ministry of

$Y u(2013)$

Heilongjiang,

2000-2009

Liaoning, Shandong, Jiangsu, Henan,

Hubei, Hunan,

Guangxi and Guizhou

Provinces Agriculture (MOA)

CHNS

\section{Local PAR officials, What are the}

in-person interviews

mechanisms by which the voluntary relocation of villagers is carried out?

What is the impact of the National 8-7 Plan on rural income growth at the county level over its disbursement period?

How can we estimate multidimensional poverty from a health and nutrition perspective? positive relationship between

household involvement in

microfinance programs and benefit.

- PAR generally does not jeopardize livelihoods.

- The displaced population experienced an increase in income and was given new economic opportunities and access to better social services.

- The displaced retained their productive capacity and enjoyed better housing quality.

- the 8-7 Plan resulted in an approximately 38-percent increase in rural income for counties that were treated between 1994 and 2000.

- Initial endowments are important in future economic development.

- Rapid economic growth has resulted not only in a reduction in income poverty but also in a reduction in multidimensional poverty in the last decade.

- However, there are disparities across provinces and between urban and rural areas (poverty is 1.5 times higher in rural areas than in urban ones in 2009) 


\begin{tabular}{|c|c|c|c|c|c|c|}
\hline Rogers (2014) & $\begin{array}{l}\text { Ji County, Shanxi } \\
\text { Province }\end{array}$ & 2012,2013 & $\begin{array}{l}\text { Survey interview } \\
\text { using structured } \\
\text { questionnaire }\end{array}$ & $\begin{array}{l}\text { What is the pattern of } \\
\text { resource allocation in } \\
\text { terms of poverty } \\
\text { alleviation and rural } \\
\text { development in one of } \\
\text { China's poverty } \\
\text { counties? }\end{array}$ & - & $\begin{array}{l}\text { The county government is 'betting on } \\
\text { the strong': concentrating resources in } \\
\text { villages with better existing conditions } \\
\text { or potential for development. } \\
\text { Unfortunately, the poorer villages who } \\
\text { are in greater need, suffer from an } \\
\text { inequitable resource allocation. }\end{array}$ \\
\hline You (2014) & $\begin{array}{l}\text { Jiangsu, Shandong, } \\
\text { Henan, Hubei, Hunan, } \\
\text { Guangxi and Guizhou } \\
\text { Provinces }\end{array}$ & $\begin{array}{l}1989 \\
1991, \\
1993 \\
1997 \\
2000,2004 \\
\text { and } 2006\end{array}$ & $\begin{array}{l}\text { China Health and } \\
\text { Nutrition Survey } \\
\text { (CHNS) }\end{array}$ & $\begin{array}{l}\text { How can we better } \\
\text { understand the persistent } \\
\text { hardship in some Chinese } \\
\text { rural households from } \\
\text { the perspective of assets, } \\
\text { stressing the long-run } \\
\text { implications of shocks } \\
\text { and risk on households' } \\
\text { agricultural asset } \\
\text { holdings (i.e. why has } \\
\text { poverty persisted)? }\end{array}$ & - & $\begin{array}{l}\text { Overall, households' responses to } \\
\text { uninsured shocks and risk cause } \\
\text { inefficiencies and deficiencies of } \\
\text { investment in agricultural asset } \\
\text { accumulation. } \\
\text { Multiple equilibria in the dynamics of } \\
\text { household agricultural assets as well } \\
\text { as under-investment as a response to } \\
\text { risk make some households less able to } \\
\text { earn income above the poverty line } \\
\text { and keep them trapped in long-term } \\
\text { low-equilibrium asset poverty. }\end{array}$ \\
\hline $\begin{array}{r}\text { You and Annim } \\
\text { (2014) }\end{array}$ & Gansu Province & 2000,2004 & $\begin{array}{l}\text { Gansu Survey of } \\
\text { Children and } \\
\text { Families (GSCF) }\end{array}$ & $\begin{array}{l}\text { What are the effects of } \\
\text { formal microcredit } \\
\text { programs on children's } \\
\text { educational outcomes in } \\
\text { northwest rural China? }\end{array}$ & - & $\begin{array}{l}\text { There is a significant positive impact } \\
\text { of microcredit on children's schooling } \\
\text { years in } 2000 \text { only. } \\
\text { There appears to be no relationship } \\
\text { between academic performance and } \\
\text { microcredit programs in both } 2000 \\
\text { and } 2004 \text {. }\end{array}$ \\
\hline
\end{tabular}




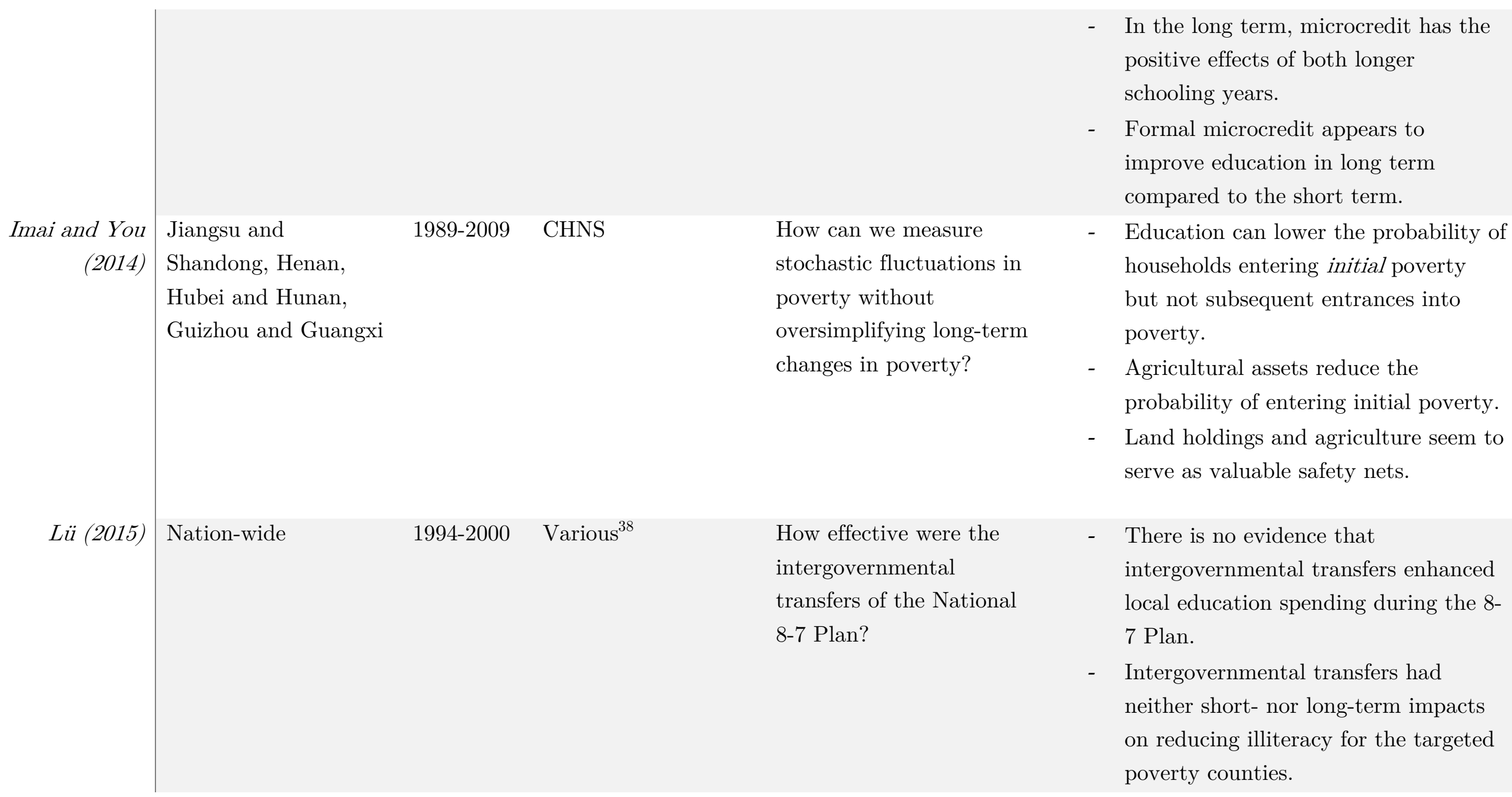

${ }^{38}$ China Education Finance Statistical Yearbooks, National Prefecture and County Finance Statistics Compendium, Compulsory Education in National Poor Regions Project. 


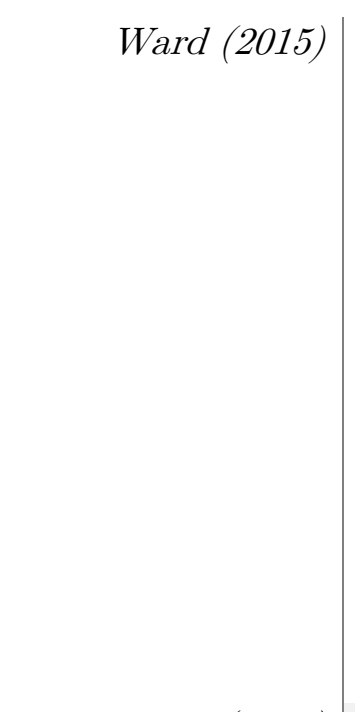

Qi and $W u(2015)$
1991-2006

Guangxi, and Guizhou

$\begin{array}{lll}\text { Heilongjiang, } & \text { 1989-2009 } & \text { China Health and } \\ \text { Liaoning, Shandong, } & \text { Nutrition survey } \\ \text { Jiangsu, Henan, } & \text { (CHNS) } \\ \text { Hubei, Hunan, } & \\ \text { Guizhou and Guangxi } & \end{array}$

(1) How can we more robustly differentiate between transient or chronic poverty? (2) How can we represent the dichotomy using probabilities instead of using traditional poverty indicators, which are merely snapshot summaries of poverty dynamics?

(1) What is the multidimensional child poverty status and its dynamic changes in China from 1989 to 2009? (2) Do certain geographic regions receive more poverty alleviation than others?
- Most households shifted from chronic to transient.

- Vulnerability to poverty declined over time, despite intermediate variability in the declines.

- By 2006, most of the poverty observed is due to transitory income shocks and not entrenchment in chronic poverty $^{40}$.

- the overall rate of poverty declined during this period, largely because of the reduction of child poverty, signifying an improvement in child living conditions.

- All poverty headcount ratios in different provinces were reduced over time, but provinces with middle economic growth rates oversaw the

\footnotetext{
${ }^{39}$ CHNS is an ongoing open cohort, international collaborative project between the Carolina Population Center at the University of North Carolina and the National Institute for Nutrition and Health at the Chinese Center for Disease Control and Prevention (CCDC). It is designed to examine the effects of the health, nutrition, and family planning policies and programs implemented by national and local governments and to see how the social and economic transformation of Chinese society is affecting the health and nutritional status of its population.

${ }^{40}$ Despite the positivity of the reduction of chronic poverty, the consistency of transitory income shocks from 1991 to 2006 raises the concern that policies were not been able to prevent transitory entrance into poverty.
} 


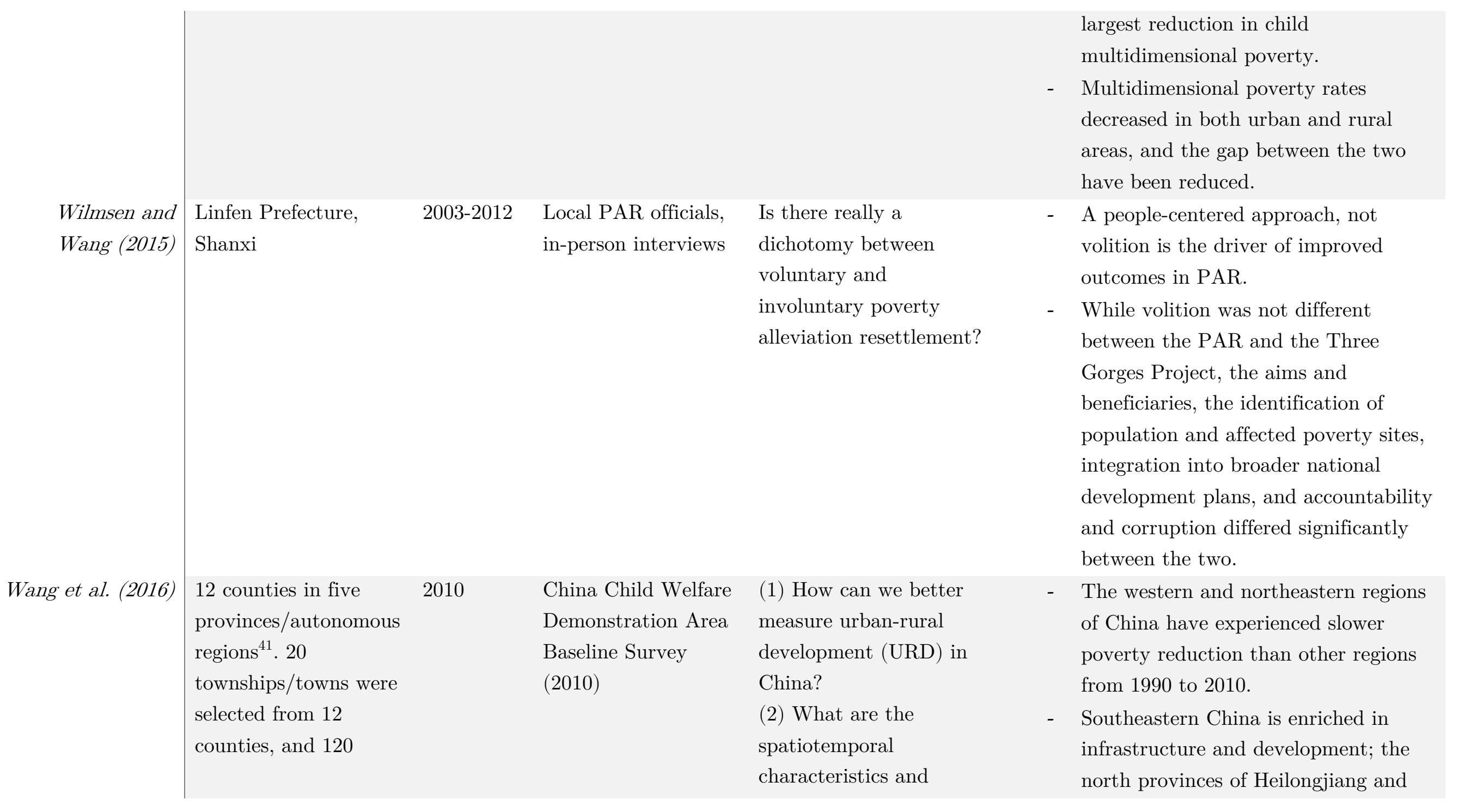

\footnotetext{
${ }^{41}$ Sichuan, Yunnan, Henan, Xinjiang Uygur autonomous region, and Shanxi.
} 


\begin{tabular}{|c|c|c|c|}
\hline & $\begin{array}{l}\text { villages were further } \\
\text { selected. }\end{array}$ & & \\
\hline $\begin{array}{r}\text { Wang and Wang } \\
(2016)\end{array}$ & $\begin{array}{l}\text { Hechi City, Guangxi } \\
\text { Zhuang Autonomous } \\
\text { Region, China, and is } \\
\text { a part of Yunnan and } \\
\text { Guangxi and Guizhou } \\
\text { rocky desertification } \\
\text { areas. }\end{array}$ & 2013 & $\begin{array}{l}2013 \text { Census Data, } \\
\text { poverty alleviation } \\
\text { department of Hechi } \\
\text { City }\end{array}$ \\
\hline Yang et al. (2016) & Shaanxi Province & 2013 & $\begin{array}{l}5^{\text {th }} \text { National Health } \\
\text { Service Survey of } \\
\text { Shaanxi Province }\end{array}$ \\
\hline Golan et al. (2017) & $\begin{array}{l}\text { Hebei, Jiangsu, } \\
\text { Zhejiang, Anhui, } \\
\text { Henan, Hubei, } \\
\text { Guangdong, } \\
\text { Chongqing, and } \\
\text { Sichuan }\end{array}$ & 2007-2009 & CHIP survey \\
\hline
\end{tabular}

internal relationships of

China's URD?

(3) What are the policy implications for achieving coordinated URD?

How can we measure multidimensional poverty in poverty-stricken counties in rural China?

What are the effects of the New Cooperative Medical Scheme (NCMS) on alleviating financialinduced health rural poverty?

What are the targeted poverty reduction implications of China's rural dibao program?
Xinjiang, and the lowest values are in southwestern China.

- The main factors contributing to poverty are: unsafe housing, family health and adult illiteracy.

- Multidimensional poverty indexes increased with an increasing degree of desertification and rocky desertification, corroborating previous findings that multidimensional poverty is strongly region-dependent.

- While the NCMS can alleviate health poverty, the coverage is lacking - the benefits of the NCMS is greater for hospital admission-insured than for general-insured; serious diseases as well as more common illnesses should receive equal attention.

- The rural dibao program provided sufficient income to poor beneficiaries, but the overall impact on poverty was small.

- Although total dibao expenditures are fairly large relative to the poverty gap, the program did not substantially 


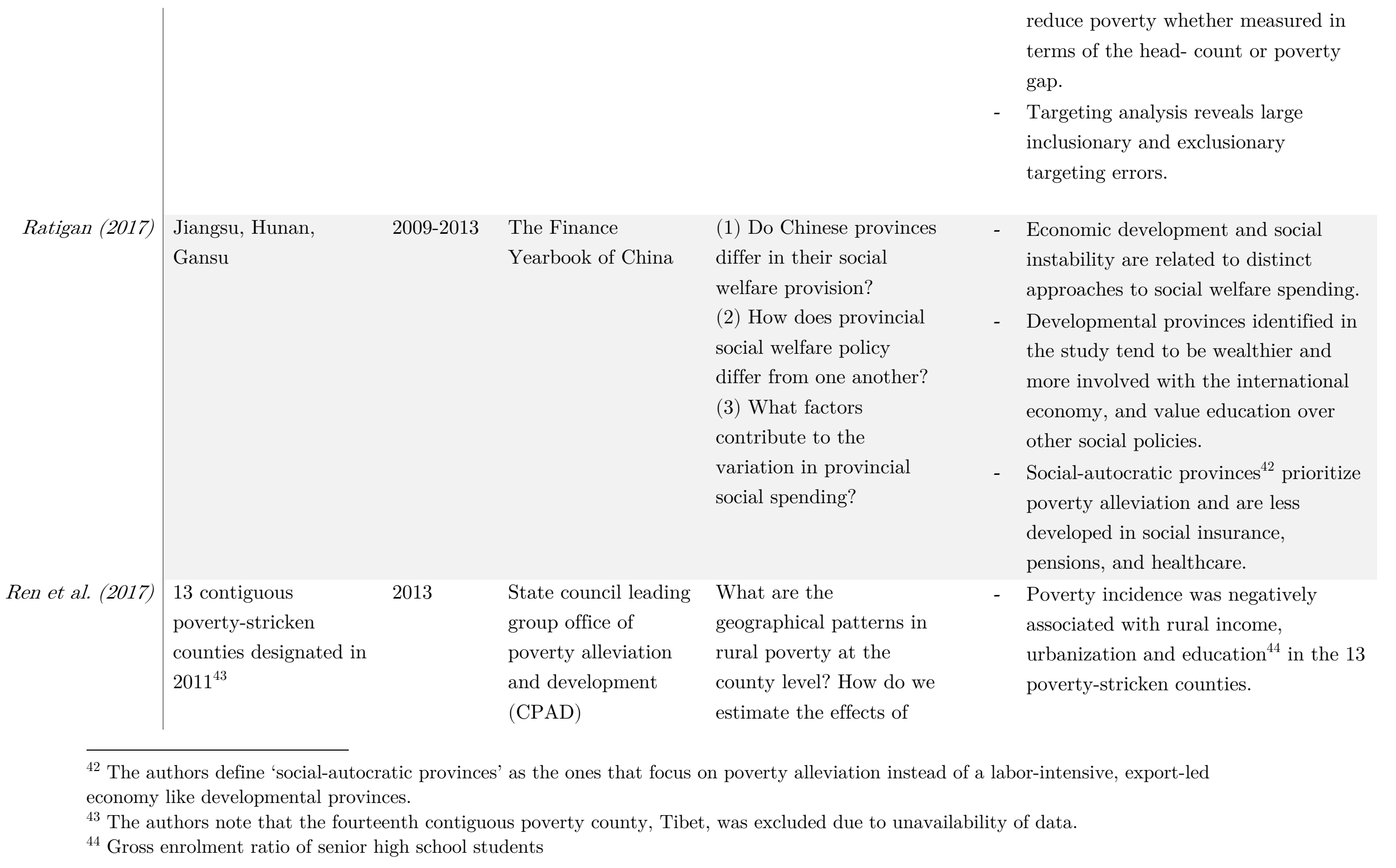




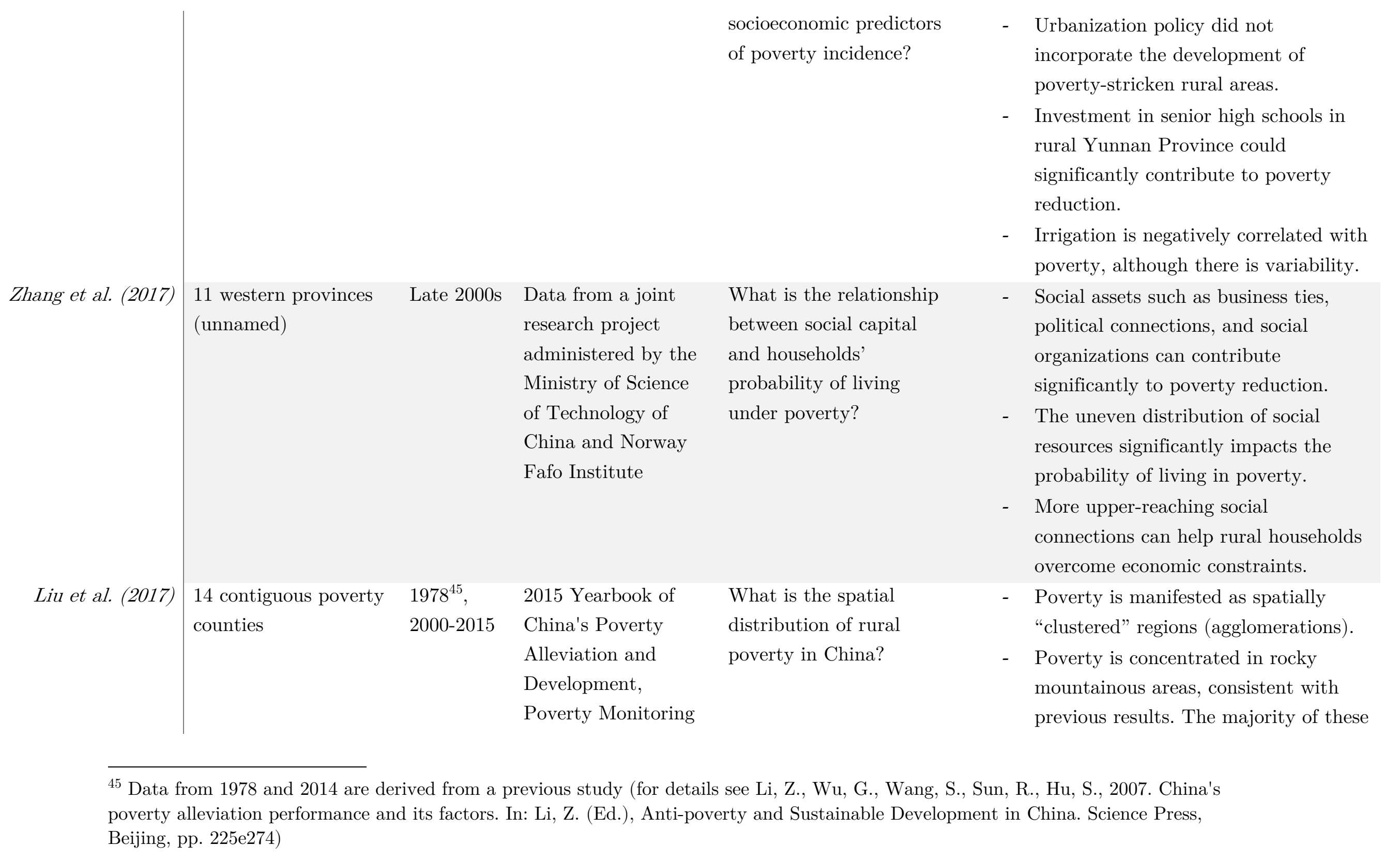


Report of Rural

China, China Rural

Statistical Yearbook

Hua et al. (2017)

$\begin{array}{lll}\text { Jinchuan county, } & \text { May-Aug } & \text { Responses from } \\ \text { Tibetian Plateau } & 2011, \text { Sep } & \text { semi-structured } \\ \text { (upper reaches of the } & 2012 & \text { interviews from 357 } \\ \text { hadu river) } & & \text { households }\end{array}$

How can we quantitatively measure the relationship between livelihood assets and livelihood strategies? areas remain plagued with both chronic and transient poverty.

- The "islanding effect" — that is, the isolation of destitute areas that lack public infrastructure and imprecise poverty alleviation measures - may be exacerbated in the future.

- There are significant differences in the livelihood assets owned by households with different livelihood strategies. Human, natural, and financial assets have significant influences on livelihood strategies, and the choice of livelihood strategy varies by livelihood assets.

- with improvements in household labor capacity and cash income per capita, the livelihood strategies of nonagricultural and non-farming households may shift away from agriculture, while an increase in farmland cultivated per capita, cash income per capita, and household labor capacity may encourage households to adopt agriculturedependent livelihood strategies 
Alkire and Shen Liaoning, Shanghai,

(2018) Guangdong, Henan and Gansu Provinces

Alkire and Fang Liaoning,

(2018) Heilongjiang, Jiangsu, Shandong, Henan,

Hubei, Hunan,

Guangxi, and Guizhou
2010-2014 China Family Panel Studies (CFPS)

All 9

rounds of

the

CHNS $^{46}$
China Health and

Nutrition Survey

(CHNS)

\section{Chen et al. (2018)}

Two counties of

2013

Ningbo City,

Zhejiang.

What are the national

levels of rural

multidimensional

poverty?

How can we paint a more

complete picture of

poverty in rural China

by combining traditional

income poverty measures

and new

multidimensional poverty

measures?

What are the equity

impacts of the NCMS in

rural China?
- Dimensions such as nutrition, education, safe drinking water and cooking fuel aggravate overall nonfiscal poverty.

- Both the income poverty and multidimensional poverty decline quickly as the time goes, and rural multidimensional poverty is more severe than urban areas, especially in sanitation, drinking water and cooking fuel, it mainly attributes to the segregation produced by the China's registration system and its induced formed rural living habits, lagged infrastructure construction and high transformation costs.

- Rural education and rural malnutrition are still not very optimistic.

- While NCMS has improved its coverage and generally alleviated the economic liability of illnesses, its impact on mitigating the economic vulnerability of illness and promoting equity in health services is negligible.

${ }^{46} 1989,1991,1993,1997,2000,2004,2006,2009$, and 2011 
Ding et al. (2018)

Zhang et al. (2018) provinces $^{48}$

2011 ,

2013, 2015

\section{China Health and}

Retirement

Longitudinal Survey

$\left(\mathrm{CHARLS}^{49}\right)$

Tian et al. (2018)

Chinese Agricultural

Policy Village

Survey 2003

(CAPVS 2003) ${ }^{47}$

tons

14 contiguous poverty $1951-2012 \quad$ Various $^{50}$ counties
What are the antipoverty effects before and after the first government-led microfinance project in rural China?

How can we estimate the vulnerability to food poverty for the rural elderly?

How can we

quantitatively connect poverty causes and
- Microfinance projects have a statistically significant effect on improving the net income of the farmers and reducing rural poverty in China, consistent with previous findings.

- The programs prompt an increased access to non-farm activities instead of the reliance on the growth of the farm sector.

- food poverty incidence and vulnerability of the elderly with chronic diseases in rural China is $41.9 \%$ and $35 \%$ respectively, which is $8 \%$ and $6 \%$ higher, respectively, than the elderly that are in good health.

- The main contributing factors to poverty in the mountainous areas in eastern part of China ${ }^{51}$ are the lack of

\footnotetext{
${ }^{47}$ Admittedly, constrained by data availability, the assessment of the government-led microfinance project focuses on the average net income growth of villages but not further using individual-level data. It prevents us from examining the heterogeneity among beneficiaries, and, hence, this issue remains an interesting topic for future research.

48 the Tibet Autonomous Region was excluded

${ }^{49}$ CHARLS was a nationwide survey aiming to collect personal and familial information regarding the elderly population. People of the age 45 and older were randomly selected to be interviewed in the survey.

${ }^{50}$ GIS data, National Meteorological Administration of China Meteorological Administration, National Natural Atlas of the People's Republic of China, 2016 National Transport Digital Map of the Ministry of Communications, China County (City) Social and Economic Statistical Yearbook, China City Statistical Yearbook, China's Sixth Census Data, National Geographic Information Center.

${ }^{51}$ Namely the Dabie mountain area, the Yanshan-Taihang mountain area and the southern Greater Khingan mountain area
} 
Liu and Ma (2018) 592 592 national poverty
counties

Lo and Wang (2018)

Loess Plateau ${ }^{54}$

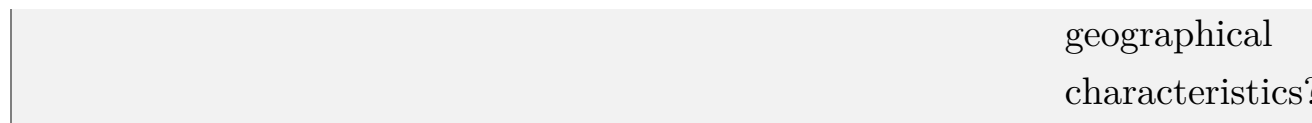

1993-2010 China's Ministry of Agriculture, China County Statistical Yearbooks, various Provincial Statistical Yearbooks

MarchJune 2013

\section{Fieldwork at 20} poverty alleviation resettlement (PAR) projects

human capital and information technology.

- The main factors behind regional poverty in the central mountain $\operatorname{areas}^{52}$ are poor transportation and infrastructure, and other natural factors.

- Western mountain regions ${ }^{53}$ are particularly susceptible to natural factors; even then, each area has a unique cause for poverty.

How effective is the National Poor Counties Program (NPC)?

How effective really is China's poverty resettlement program?
- The NPC program failed to foster local economic growth.

- Local elite capture is partly responsible for NPC's ineffectiveness.

- Placed-based poverty alleviation may be influenced by limited local accountability.

- Inconclusive and conflicting findings.

- On the one hand, the respondents strongly expressed that they willingly participated in resettlement. The perception of willingness was

\footnotetext{
${ }^{52}$ Namely the LuoXiao mountain area, the Lvliang mountain area and the Wuling mountain

${ }^{53}$ Namely Tibet, Tibetan areas in four provinces, South Xinjiang's three districts and the West Yunnan border area

${ }^{54}$ Also known as the Huangtu Plateau. It spans Shanxi, Shaanxi, Ningxia, and Gansu Provinces and extends into some parts of Inner Mongolia.
} 


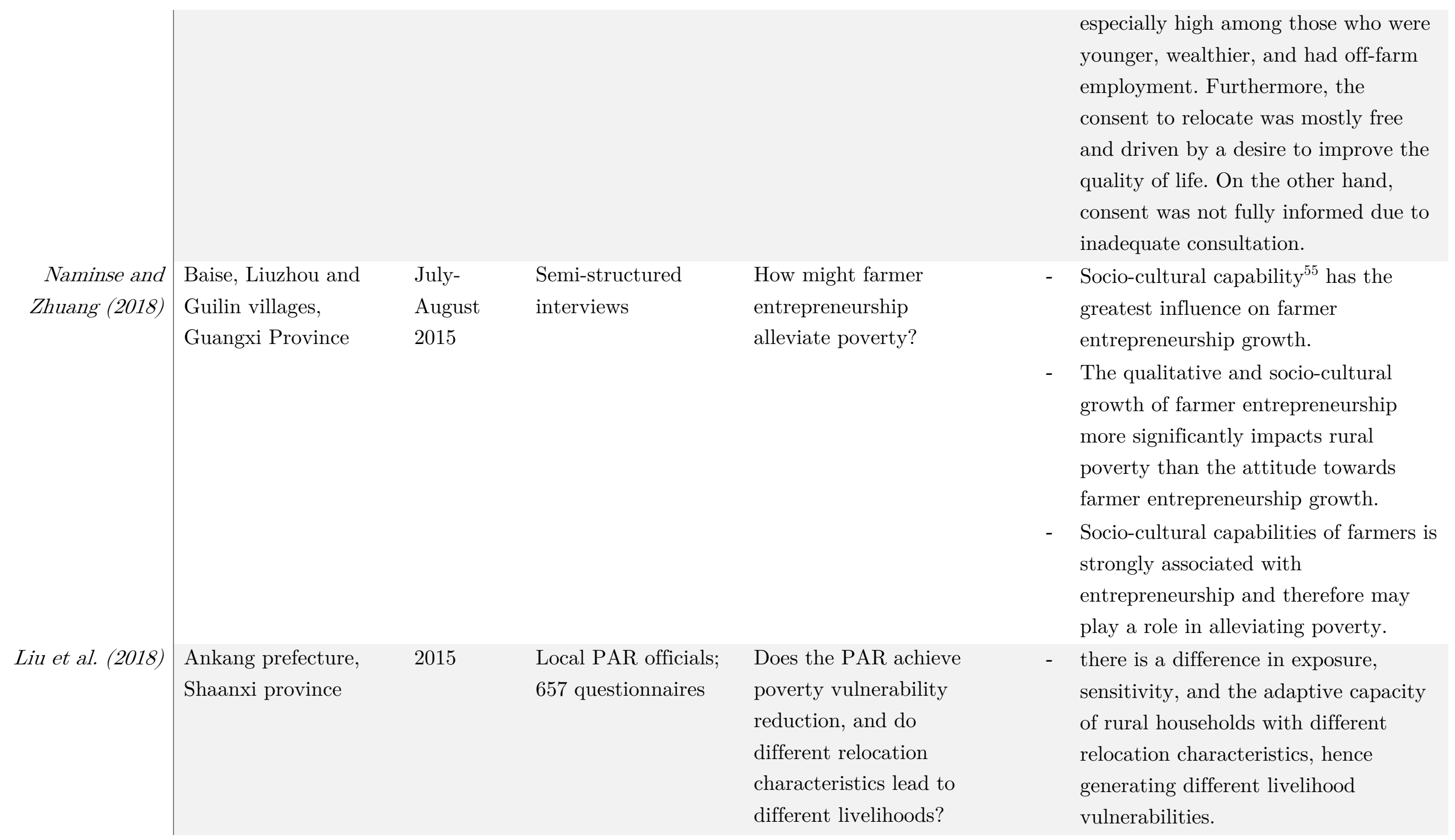

${ }_{55}$ The authors define this as social interactions, networking capabilities, improved culture and available opportunities to farmers. 
Hanbin, Ziyang, Shiquan, Pingli, and Ningshan Counties of Ankang prefecture

15 poor counties from Guangxi province $^{58}$

\section{5}

\section{Primary cross- sectional survey data $^{56}$, semi-} structured interviews

\section{D}

influence resettlement

outcomes? (3) Does the reason for PAR matter?

(4) How do the types of relocation $^{57}$ play a role in PAR projects?
- Project-induced relocation has a significant positive effect on

vulnerability, but there is a significant negative correlation between

livelihood vulnerability and relocation region, relocation time, and relocation subsidy.

- Voluntary poverty, transient poverty, and chronic poverty are distinguished by combining income and consumption criteria.

- Relocated individuals and families have diverse income and consumption levels and poverty type.

- PAR has a negative correlation with chronic poverty; however, the relocated group does not have significant differences in transient and voluntary poverty compared to the non-relocated.

- The level of education and the political standing of the household

\footnotetext{
${ }^{56}$ Collected by the Institute for Population and Development Studies of Xi'an Jiaotong University. The survey used a multi-stage stratified sampling design and structured questionnaires.

${ }^{57}$ Centralized, scattered, township/urban, or self-determined.

58 The authors conducted a pre-survey to adapt the questionnaires to be more targeted towards the regional circumstances of Xingye county, one of the 64 poor counties in Guangxi province.
} 


\begin{tabular}{|c|c|c|c|c|c|}
\hline & & & $\begin{array}{l}\text { Whole Village } \\
\text { Poverty } \\
\text { Alleviation Program }\end{array}$ & $\begin{array}{l}\text { alleviation programs } \\
\text { affect household } \\
\text { incomes? }\end{array}$ & $\begin{array}{l}\text { head is a major factor in program } \\
\text { participation. } \\
\text { - The poor receive less benefits than the } \\
\text { rich. } \\
\text { - Increased villager participation in } \\
\text { discussion and voting can boost the } \\
\text { effectiveness of poverty alleviation } \\
\text { programs. }\end{array}$ \\
\hline Shen et al. (2019) & $\begin{array}{l}25 \text { provinces, } \\
\text { municipalities and } \\
\text { autonomous regions }{ }^{59}\end{array}$ & 2010-2014 & $\begin{array}{l}\text { CFPS 2010, } 2012 \\
\text { and } 2014\end{array}$ & $\begin{array}{l}\text { What is the state of } \\
\text { multidimensional poverty } \\
\text { nationwide? }\end{array}$ & $\begin{array}{l}\text { While nationwide levels of } \\
\text { multidimensional poverty decreased } \\
\text { over time, that decrease is } \\
\text { disproportional across regions. }\end{array}$ \\
\hline $\begin{array}{r}\text { Han and Gao } \\
\text { (2019) }\end{array}$ & $\begin{array}{l}162 \text { counties across } 25 \\
\text { provinces }\end{array}$ & 2012-2014 & CFPS 2012 and 2014 & $\begin{array}{l}\text { (1) How does the rural } \\
\text { dibao program affect life } \\
\text { satisfaction of the } \\
\text { recipients? (2) To what } \\
\text { extent does optimism or } \\
\text { pessimism, as well as } \\
\text { perceived social status, } \\
\text { play a role in the dibao's } \\
\text { impacts? }\end{array}$ & $\begin{array}{l}\text { Dibao participation generally boosts } \\
\text { the rural poor's life satisfaction. } \\
\text { The increase in satisfaction can be } \\
\text { explained by the recipients' higher } \\
\text { perceived social status and optimism, } \\
\text { in contrast to the recipients of urban } \\
\text { dibao from a separate study. }\end{array}$ \\
\hline $\begin{array}{r}\text { Kakwani et al. } \\
\text { (2019) }\end{array}$ & $\begin{array}{l}\text { Beijing, Liaoning, } \\
\text { Jiangsu, Shandong, } \\
\text { Guangdong, Shanxi, } \\
\text { Anhui, Henan, Hubei, } \\
\text { Hunan, Gansu, }\end{array}$ & 2013 & $\begin{array}{l}2013 \text { Chinese } \\
\text { Household Income } \\
\text { Project (CHIP } \\
\text { 2013), Subset of the } \\
\text { NBS annual RHS }\end{array}$ & $\begin{array}{l}\text { To what extent does the } \\
\text { dibao program meets its } \\
\text { intended objective of } \\
\text { reducing rural poverty? }\end{array}$ & $\begin{array}{l}\text { the rural dibao program suffers from } \\
\text { very low targeting accuracy, high } \\
\text { exclusion error, and inclusion error, } \\
\text { and yields a significant negative social } \\
\text { rate of return. }\end{array}$ \\
\hline
\end{tabular}

${ }_{59}$ The authors exclude excluding Xinjiang, Qinghai, Inner Mongolia, Ningxia, Tibet, Hainan, Hong Kong, Macao and Taiwan. 
Sichuan, Chongqing,

and Yunnan

Yang and $\mathrm{Fu}$

21 provinces

2010-2016

CFPS

Does inclusive finance

programs play a role in

multidimensional

poverty?
- Labor capacity influences poverty alleviation outcomes in financial development

- Financial institutions can achieve both sustainable development and poverty alleviation by targeting the services more precisely to the workingage population in rural areas.

\section{Appendix B: Empirical methods}

\section{Authors of Empirical method and usage} study

Travers and A variable elasticity model to gauge aggregate

Ma (1994)

Chen and Two poverty lines (on the basis of the standard Ravallion poverty line made by the State Statistics

(1996) Bureau) to measure the extent to which rural populations are considered poor.

\section{Data source}

China's County Level Rural Economic Statistical Abstract

Rural Household Survey (RHS); in-person interviews with county officials

\section{Research question(s)}

Can the agricultural intensification and investment raise peasant incomes in poor areas?

(1) How can we better understand and validate poverty rates from existing data (i.e. how can we improve data-collecting methods)? (2) How can we corroborate the concerns of policymakers regarding the effectiveness of the policies in the 1980s? 
Jalan and A poverty index to measure household-level

Ravallion consumption over time.

(1998)

Jalan and

Ravallion

(1999)

Carrin et al.

(1999)

Summary statistics of reimbursement structure

in the selected counties.

Tobit and logit models to estimate transient and

Jalan and

Ravallion

(2000)

Jalan and

Ravallion

(2001)

Park et al.

(2002)

Hannum

(2003)

Mcculloch and

Calandrino

(2003)

Generalized Method of Moments to estimate risk insurance.

chronic poverty.

A nonlinear dynamic model to take into account

long-term fluctuations in mean household

income.

Propensity-score matching method to measure regional differences in targeting.

Binary logit models to test the impact of

community characteristics (topography,

demography) on the prediction of educational provision.

A vulnerability measure (based on the probability of being in poverty in any given

year) to measure the relationship between

chronic poverty and poverty vulnerability.
RHS

Rural Household Survey

(RHS)

Data is based off of Carrin et al. (1996)

\section{Rural Household Survey (RHS)}

Data from Jalan and Ravallion (1998), Jalan and Ravallion (1999)

National panel data

Rural component of the National Sample Survey of the Situation of Chinese Children

Household Survey Division of the Rural Survey

Organization in the National Bureau Statistics (NBS)
How can we better understand and measure the extent of poverty through different time scales $^{60}$ ?

To what extent are the needs of households in poor rural economies similar or different, and does the existing consumption insurance work better for some groups than others?

(1) To what extent have counties and their townships been able to reduce the burden of healthcare costs on the rural population?

(2) How effective are the policies' population coverage and how adequate is the reimbursement structure?

Is transient poverty is determined by a process that is similar to chronic poverty?

How do characteristics of household income dynamics influence the long-term effects of a transient shock?

How effective is regional targeting in alleviating rural poverty?

(1) How do local community resources influence educational inequality? (2) In what ways do village characteristics affect children?

How chronic is poverty in China? 
Ravallion and Chen (2005)

Cheng (2007)

Difference-in-difference (DID) to measure differences in outcomes between the treatment and non-treatment group before and after project implementation

Grameen methodology to test the sustainability and effect of microfinance projects.

Montalvo and Regression models to determine whether the

Ravallion pattern of China's growth played a significant role in poverty reduction.

Goh et al. Growth incidence curve ${ }^{61}$ and the Poverty-

(2009) Growth-Inequality arithmetic ${ }^{62}$ to measure the extent of change in income growth over time.

Turvey and Summary statistics on farm household attributes Kong (2010) and ran a Bonferroni test against the null hypothesis of households being equal in attributes.

Duclos et al. A new index to measure transient and chronic

(2010) poverty that is based on the Jalan-Ravallion method.

Park and Difference-in-Difference Propensity Score Wang (2010) Matching.

(DID-PSM). The authors compare incomes and
Rural Household Survey (RHS)

RHS

Sub-national panel dataset constructed by the authors and China's National and Provincial Bureaus of

Statistics

CHNS

\section{RHS}

Survey data conducted annually by China's Research Center for Rural Economy (RCRE)

A subset of the National

Bureau of Statistics (NBS) annual RHS
What is the savings behavior of beneficiaries of a large poor-area development project?

(1) What factors affect the household demand for micro-loans in an evolving economic environment?

(2) How can we understand the demand of the poor for microfinance from a behavioral perspective?

What role does economic growth-which has been highly uneven across regions since 1980play in poverty reduction?

What are the patterns of income growth and inequality nationwide from 1989 to 2004 ?

(1) What is the connection between informal and formal lending in rural China? (2) How might the strength of informal lending affect microfinance?

How can better statistical and empirical methods be employed to more accurately measure transient and chronic poverty?

How effective is community-based development (poor village investment program)?

\footnotetext{
${ }^{61}$ Adapted from the nonlinear model of Ravallion and Chen (2001).

${ }^{62}$ See Bourguignon, François (February 2004). "The Poverty-Growth-Inequality Triangle" (PDF). World Bank Website.
} 
Glauben et al. A hazard model to take into account the fact

(2011)

Li et al. (2011)

Xue et al. Descriptive surveys taken by local officials and

(2013) households.

$Y u$ (2013) Alkire-Foster (A-F) method to measure income, living standard, education, health and social security.

Meng (2013) Regression Discontinuity (RD) and DID to estimate the effectiveness of the agricultural investment program on income growth.

Rogers (2014) Qualitative data recovered from field interviews (71) with both village officials and households. Prevalence of specific village-targeted programs were also compared at the village level to evaluate the distributions of these benefits.

You (2014) Fixed-effects model to estimate the changes in consumption in response to income shocks.
Survey data conducted annually by China's Research Center for Rural Economy (RCRE)

Survey interview using structured questionnaire

Local PAR officials, inperson interviews

\section{CHNS}

Ministry of Agriculture (MOA)

Face to face interviews in Ji County.

\section{CHNS}

What are the determinants of long-term poverty and what is the duration dependence on the probability to leave poverty?

What is the impact of microfinance programs on household welfare outcomes such as income and consumption in rural China?

What are the mechanisms by which the voluntary relocation of villagers is carried out?

How can we estimate multidimensional poverty from a health and nutrition perspective?

What is the impact of the National 8-7 Plan on rural income growth at the county level over its disbursement period?

What is the pattern of resource allocation in terms of poverty alleviation and rural development in one of China's poverty counties?

How can we better understand the persistent hardship in some Chinese rural households from the perspective of assets, stressing the long-run implications of shocks and risk on households' agricultural asset holdings (i.e. why has poverty persisted)? 
You and $\mid$ Static and dynamic regression-discontinuity

Annim (2014)

igns are used to measure microfinance

programs' impact on education outcomes. The

models also control for unobservables between

borrowers and non-borrowers.

Imai and You

Lü (2015) and exit.

Fuzzy-Regression Discontinuity (Fuzzy RD); the author exploits the rolling-introduction of intergovernmental transfers for public good provision to test for signs of elite capture and corruption in local Chinese governments.

Ward (2015) Income regression model to control for both household and time effects.

A-F method to calculate dimension scores.

(2015)

Wilmsen and Wang (2015)

Presentation of descriptive accounts and survey results.
Gansu Survey of Children and Families (GSCF)

\section{CHNS}

China Education Finance

Statistical Yearbooks,

National Prefecture and

County Finance Statistics

Compendium, Compulsory

Education in National Poor

Regions Project

\section{CHNS}

CHNS

Local PAR officials, inperson interviews
What are the effects of formal microcredit programs on children's educational outcomes in northwest rural China?

How can we measure stochastic fluctuations in poverty without oversimplifying long-term changes in poverty?

How effective were the intergovernmental transfers of the National 8-7 Plan?

(1) How can we more robustly differentiate between transient or chronic poverty? (2) How can we represent the dichotomy using probabilities instead of using traditional poverty indicators, which are merely snapshot summaries of poverty dynamics?

(1) What is the multidimensional child poverty status and its dynamic changes in China from 1989 to 2009? (2) Do certain geographic regions receive more poverty alleviation than others?

Is there really a dichotomy between voluntary and involuntary poverty alleviation resettlement? 
Wang et al.

Entropy method to measure differences in urban and rural development.

Wang and Wang (2016)

Yang et al.

Golan et al.

Ratigan (2017)

Ren et al.

(2017)

Zhang et al.
A-F method and GIS spatial analysis to measure multidimensional poverty.

In-person interviews

Probit regression models (household is the unit of analysis).

Cluster Analysis, between-Effects estimation to test for evidence of statistically significant divergence in public spending patterns for provinces in China. Significant differences in spending patterns were then used to create a typology.

Multi-Level Mixed-Effect Model - The authors test for regional heterogeneities in the response of incidences of poverty to specific development variables.

Multi-Level Mixed Effects Model with Matching

- The authors control for between-group

heterogeneities using a multi-level ME model, and test whether social capital is effective in reducing the probability that a household will fall below (inter)national poverty lines.
China Child Welfare

Demonstration Area

Baseline Survey (2010)

2013 Census Data, poverty alleviation department of Hechi City

5th National Health

Services Survey (NHSS) of

Shaanxi Province

CHIP survey

The Finance Yearbook of China

State council leading group office of poverty alleviation and development (CPAD)

Data from a joint research project administered by the Ministry of Science of Technology of China and Norway Fafo Institute
(1) How can we better measure urban-rural development (URD) in China?

(2) What are the spatiotemporal characteristics and internal relationships of China's URD?

(3) What are the policy implications for achieving coordinated URD?

How can we measure multidimensional poverty in poverty-stricken counties in rural China?

What are the effects of the New Cooperative Medical Scheme (NCMS) on alleviating financial-induced health rural poverty? What are the targeted poverty reduction implications of China's rural dibao program? (1) Do Chinese provinces differ in their social welfare provision?

(2) How does provincial social welfare policy differ from one another? (3) What factors contribute to the variation in provincial social spending?

What are the geographical patterns in rural poverty at the county level? How do we estimate the effects of socioeconomic predictors of poverty incidence?

What is the relationship between social capital and households' probability of living under poverty? 
Liu et al. Spatial Autocorrelation; creation of a Moran

(2017) statistic, which indicates visually the concentration of individuals living below the national poverty line in 2015 .

Hua et al. Two-step cluster analysis to quantify household

Alkire and Shen (2018)

Alkire and

Fang (2018)

Chen et al. Multi-stage stratified cluster random sampling

Ding et al. method to draw the study sample.

\section{Difference-in-Difference Propensity Score}

Matching.

(DID-PSM) The authors use panel data on villages between 1998 and 2003 to compare incomes in villages that undertook microfinance programs to those that did not.

Zhang et al. Three-Stage Feasible GLS - The authors create a
2015 Yearbook of China's

Poverty Alleviation and

Development, Poverty

Monitoring Report of Rural

China, China Rural

Statistical Yearbook

Responses from semistructured interviews from

357 households

\section{CFPS}

\section{CHNS}

In-person interviews were conducted using a questionnaire

Chinese Agricultural Policy Village Survey 2003

(CAPVS 2003) ${ }^{63}$
What is the spatial distribution of rural poverty in China?

How can we quantitatively measure the relationship between livelihood assets and livelihood strategies?

What are the national levels of rural multidimensional poverty?

How can we paint a more complete picture of poverty in rural China by combining traditional income poverty measures and new multidimensional poverty measures?

What are the equity impacts of the New Cooperative Medical Scheme (NCMS) in rural China?

What are the anti-poverty effects before and after the first government-led microfinance project in rural China?

How can we estimate the vulnerability to food poverty for the rural elderly?

\section{Retirement Longitudinal}

China Health and Survey $\left(\right.$ CHARLS $\left.^{64}\right)$

\footnotetext{
${ }^{63}$ Constrained by data availability, the assessment of the microfinance program focuses on the average income growth of villages, not households or individuals

${ }^{64}$ CHARLS was a nationwide survey aiming to collect personal and familial information regarding the elderly population. People of the age 45 and older were randomly selected to be interviewed in the survey.
} 
household will fall below a specific level of caloric intake.

Tian et al. Creates a topography index to quantify destitute Several topographic areas then investigates the links between certain geographic features and regional poverty.

Liu and Ma Regression Discontinuity (RD). The authors exploit the discontinuous cut-off for the National Poverty County (NPC) program to compare development outcomes between participant and non-participant villages.

Lo and Wang Household surveys and semi-structured

Naminse and Structural Equation Modelling (SEM). The Zhuang (2018)

Liu et al. (2018)

Liu et al.

(2019)

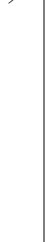

\section{databases (SPI, DEM} databases)

Income Survey Data Chinese Ministry of Agriculture (1992) China County Statistical Yearbooks (2010) Provincial Statistical Yearbooks (2010) Fieldwork at $20 \mathrm{PAR}$ projects

\section{Survey Data in Guangxi}

Province correlations between farmer entrepreneurship and rural poverty rates Creation of Livelihood Vulnerability Index (1-13) Originating from cross-sectional survey of rural living practices. Higher value $=$ less vulnerable. Multinomial logistic model to measure the relationship between relocation, settlement and type of poverty (voluntary, transient, chronic).
Are there regionally-specific determinants of poverty in China?

Have there been any short run $(1994-2000)$ or long run (1994-2010) impacts from the NPC program?

How effective really is China's poverty resettlement program?

How might farmer entrepreneurship alleviate poverty?

Does the PAR achieve poverty vulnerability reduction, and do different relocation characteristics lead to different livelihoods? (1) What is the role of voluntary, chronic, and transient poverty in the surveyed counties? (2) Does relocation time influence resettlement outcomes? (3) Does the reason for $\mathrm{PAR}$ matter?

${ }^{65}$ Collected by the Institute for Population and Development Studies of Xi'an Jiaotong University. The survey used a multi-stage stratified sampling design and structured questionnaires. 
Lin et al. Propensity score matching (PSM) to estimate

(2019) the impact of the program with restrictions on the observed exogenous factors.

Shen et al.

(2019)

Han and Gao

(2019)

(works synergistically with

invariant unobservable heterogeneity) to

estimate program impact.

Yang and $\mathrm{Fu}$ Evolutionary game model to evaluate the

(2019)

Kakwani et al.

(2019) equilibrium strategies of financial institutions and the poor in poverty reduction programs Population Proportions and Population Averages - The authors create population averages from National-level survey data then test the changes in the proportions as impacted by povertyalleviation programs.
Rural household data from China's Whole Village

Poverty

Alleviation Program

CFPS 2010, 2012 and 2014 What is the state of multidimensional poverty

CFPS

2013 Chinese Household

Income Project (CHIP

2013), subset of the NBS

annual RHS nationwide?

(1) How does the rural dibao program affect life satisfaction of the recipients? (2) To what extent does optimism or pessimism, as well as perceived social status, play a role in the dibao's impacts?

(4) How do the types of relocation ${ }^{66}$ play a role in PAR projects?

How does participation in discussion and voting in rural poverty alleviation programs affect household incomes?

Does inclusive finance programs play a role in multidimensional poverty?

To what extent does the dibao program meets its intended objective of reducing rural poverty?

\section{Appendix C: Explanatory variables}

\section{Authors of study Explanatory variables (indicators of poverty)}

Travers and Ma Income, output, labor, land, mechanical power, irrigation area, fertilizer consumption.

(1994)

${ }^{66}$ Centralized, scattered, township/urban, or self-determined. 
Chen and Ravallion

(1996)

Jalan and Ravallion

(1998)

Jalan and Ravallion (1999)

Jalan and Ravallion

Carrin et al. (1999)

Jalan and Ravallion

(2001)

Park et al. (2002)

Hannum (2003)

Mcculloch (2003)

Ravallion and Chen

(2005)

Head-count index $(\mathrm{H})$, poverty gap index $(\mathrm{PG})$, squared poverty gap index (SPG).

Mean consumption, poverty line, household size, level of education of household head (hh), wealth of hh, standard deviation (SD) of hh wealth, mean agricultural yield.

Richest decile, $70-90^{\text {th }}$ percentile, $40-70^{\text {th }}$ percentile, $40^{\text {th }}$ percentile, poorest decile.

Household size, proportion of children (6-11 years, 12-14 years, 15-17 years), age of household head, proportion of adults, illiterate proportion of adults (either primary school educated or secondary school educated), highest education of labor: primary, middle, or secondary school (dummy), household member works in state sector (dummy), household member works in TVE's (dummy), household member works out of town (dummy), mean and SD of grain yield, mean and SD of wealth per capita, cultivated land per capita, geographical feature (plains, coast, or mountains), Border area (dummy), Minority area (dummy), medical persons per 10,000 population in county.

Average income, average health expenditure, population coverage, level of insurance.

Household income and consumption.

Average income in other counties in prefecture, percent of other counties in pref. designated poor (1986-1992), percent of other counties in pref. designated poor (1993-1995).

Village income, population, labor force, irrigated land, terrain, electrification, educational infrastructure.

Household size, dependency ratio, old revolutionary area, minority area, female-headed household, flat-land/adult (acres) hilly land/adult (acres), lake area/adult (acres), value of assets, head with no or primary education, proportion of illiterate males in hh, proportion of illiterate females in hh, located in hilly area, located in mountainous area.

Geographical feature (plains, hills, mountainous), net income per capita, whether village has electricity or telephones, access to TV transmission, distance to nearest market, distance to nearest county town, distance from village to township ( $5 \mathrm{~km}, 5-10 \mathrm{~km}$ or 10-20 km), main mode of transportation used by villagers (bicycle, bus or other ), nearest train and bus station, whether village has a day-care center, nearest elementary school, nearest middle school, nearest medical clinic, elevated and forest land $(\mathrm{mu})$, cultivated land per capita $(\mathrm{mu})$, grassland per capita $(\mathrm{mu})$, whether village has TVE and \% of people work in TVE, output of grain per capita $(\mathrm{kg} /$ person), (End of year) \# of pigs, cows, sheep, goat, poultry, and honey bee per person, workforce per capita, average household size. 
Cheng (2007) Loan demand, hh income ${ }^{67}$, head school, partner school, head skill, labour ratio, official status, wage ratio, off-farm ratio, land area, Event $2004^{68}$, RCC loan, informal loan.

Montalvo and Counterfactual vector of rates of poverty reduction, counterfactual change in the headcount index, counterfactual of the Ravallion (2009) average growth of each sector.

Goh et al. (2009) Age of household head, average age of other adults excluding household head, completed years of formal education of household head, dummy of coastal provinces, occupation of household head, number of skilled workers in the household excluding, type of firm of household head, number of household members with an occupation outside of agriculture, household's farmed land per member, participation in off-farm activities.

Turvey and Kong Years of farming, farm size, total household income, \% income from farming, number of people living in household,

(2010) outstanding debt, amount of debt, asset value, informal loan value, formal loan value, both informal and formal loan value, debt to asset ratio.

Duclos et al. (2010) Transient and chronic poverty ${ }^{69}$.

Park and Wang Net income, consumption expenditures, education of the household head, household size, number of laborers, number of (2010) out-migrants, and cultivated land area.

Glauben et al. (2011) Household size, age of head Dependents, elementary, secondary, and higher education, hukou, cadre, farm characteristics, land size, asset value, cropping $\mathrm{HHI}^{70}$, village characteristics, unutilized labor force, migration, population density, geographical features (plain, mountains), average village income.

Li et al. (2011) Household annual income, household annual consumption.

Xue et al. (2013) Unspecified, presumably satisfaction levels of resettlement.

Meng (2013) National poor counties, non-national poor counties.

$Y u$ (2013) Per capita income of household, access to clean water, access to improved sanitation facilities, access to electricity, access to improved cooking fuel, body Mass Index (BMI), completion of primary school, medical insurance

Rogers (2014) Registered population (hukou), natural villages, poverty resettlement villages, approximate gross per capita income (RMB), primary production, 2012 apple production (tonnes), land, farming area, converted sloping land, infrastructure, shops, access to health clinic, cold storage, public transport.

You (2014) hh per capita consumption, hh size, age of hh head, \# years of education for hh head, \% male members in hh, \% off-farm employment in hh, agricultural and business assets, consumer durables, housing, human capital, covariate income shock,

\footnotetext{
${ }^{67}$ Separated into net family income per capita and net family income per capita squared.

${ }^{68}$ Whether the family had large events in 2004, including wedding, funerals, and house-building.

69 The authors used the same money-metric indices as Jalan and Ravallion (1998).

${ }^{70}$ Hirschman-Herfindal-Index of household income sources.
} 
You and Annim

(2014)

Imai and You (2014)

Lü (2015)

Ward (2015)

Qi and $W u$ (2015)

Wilmsen and Wang

(2015)

Wang et al. (2016)

Wang and Wang

(2016)

Yang et al. (2016)

Golan et al. (2017)

Ratigan (2017)

Ren et al. (2017) idiosyncratic income shock, \# of ill members, \# of deaths, wedding/dowry/funeral (binary), price shock of agricultural input and output, \% sown land affected by natural disasters, dependency ratio, out-migration networks, on-farm labor ratio.

Children's educational outcomes, quantity and quality of education, schooling, academic performance.

hh per capita consumption, hh size, age of hh head, \% primary, secondary, and tertiary education, index of agricultural assets, small hh business, \% local non-agricultural employment in hh, \% village out-migration, $\%$ hh members having health insurance, $\% \mathrm{hh}$ members having commercial insurance, $\% \mathrm{hh}$ members having free government insurance, $\% \mathrm{hh}$ members having cooperative insurance, extent of urbanization, economic activity, access to markets, social services, purchasing price change of farm products, \% cultivated land in natural disasters.

Log education spending per capita, log budgetary education spending per capita

Age of hh head, number of dependents, \# of working age hh members, female-headed hh (=1), education of hh head, avg. education of hh members, Land Area Cultivated, Agricultural capital index, business capital index, commuting near opentrade area (binary), $\%$ agricultural employment in community, $\%$ migrants in community.

Nutrition, water, sanitation facilities, shelter, education, health, information.

Satisfaction levels of resettlement, volition of resettlement, living conditions pre- and post-resettlement.

Economic development, urban-rural livelihood, urban share, employment structure, industrial structure, ratio of urbanbuilt land, urban-rural income gap, urban-rural consumption comparison, industrial labor, productivity disparity.

Unsafe housing, family health, adults' illiteracy, fuel type, children enrollment rate, degree of rocky desertification and topographic fragmentation.

Gender, age groups, marital status, education status, employment status, economic status.

Household size, average age of adult household members, household member with bad health or is disabled, household member with migrant job, share of income from wages, share of income from non-agricultural business, access to appliances, access to motorized transport, frequency of natural disaster, marriage in household, death in household, log housing area, share of housing area that is multi-story, household cultivated land area (mu), water flush toilet, piped water, revolutionary area, mountainous area, road covered by asphalt/cement, distance to township government.

Human capital, exports and imports, political instability, public security spending, wealth, ln (GRP), needs, dependency ratio, inequality (20:20 ratio), illiteracy (\%), central transfers, fiscal transfers, key universities, social safety net transfers, control variables, population, urban (\% of population).

Poverty incidence (\%), Rural income (Yuan/person), Urbanization (\%), Senior high school (\%), Village nursery (\%), Road density (kilometres/square kilometres) Grain production (kilogramme/person), Irrigated land ratio (\%). 
Zhang et al. (2017) Household social capital, social networks.

Liu et al. (2017) Spatial distribution characteristics of poverty in rural China.

Hua et al. (2017) Non-farm activity, land transfer, livestock input, self-employment, non-farm income per capita, crop income.

Alkire and Shen Nutrition, education, safe drinking water, cooking fuel, gender of the household heads, age, education level, marital status,

(2018) household size, migration status, ethnicity, and religion.

Alkire and Fang Education, health, living standard.

Chen et al. (2018) Number of peasants, annual per capita income (RMB), consumption per capita (RMB), medicine expenditure per capita (RMB), NCMS coverage rate (\%), villager's pay for NCMS (RMB), NCMS reimbursement rate (\%).

Ding et al. (2018) Log of annual nonfarm income per capita, Log of annual farm income per capita, Share of households with family business, share of households engaged in farm activities, number of villages.

Zhang et al. (2018) Degree of voluntarism, Social connections, Incomes and expenses, Post-resettlement satisfaction

Lo and Wang (2018) Relocated, relocation type, relocation region, relocation time, and relocation subsidy.

Liu et al. (2018) Per capita real disposable income, per capita real household consumption.

Liu et al. (2019) Voluntary, chronic, and transient poverty.

Lin et al. (2019) Age of household head, education of household head, family size Number of people living in the household, family labor, land area $(\mathrm{mu})$, party membership, village population.

Shen et al. (2019) Education, health, living standard.

Han and Gao (2019) Satisfaction with own life, satisfaction with household well-being, perceived social status, confidence about the future.

Yang and Fu (2019) Permeability, usability, utility, quality, affordability ${ }^{71}$.

Kakwani et al. (2019) Disposable income consumption, total rural population and number of poor and nonpoor (million), Gini index, official poverty line (Yuan per year), \% of poor, poverty gap ratio \%, severity of poverty \%; welfare indicators: per capita household welfare (Yuan per year), per capita household welfare of poor (Yuan per year), per capita household welfare of non-poor (Yuan per year), per capita welfare of dibao beneficiaries (Yuan per year), beneficiary incidence (\% of beneficiaries), total number of beneficiaries (million), number of poor included in dibao (million), number of poor excluded from dibao (million), Exclusion error (\% of poor excluded), number of non-poor included in dibao (million), \% of beneficiaries among the poor, $\%$ of beneficiaries among non-poor (inclusion error), leakage (\% of all beneficiaries from nonpoor), benefit incidence, average transfer in the population (Yuan per year), average transfer among the poor (Yuan per year), average transfer among the non-poor, total transfers going to beneficiaries per year (billion), total transfers going to

\footnotetext{
${ }^{71}$ The variables are part of the inclusive financial development index system.
} 
poor beneficiaries (billion), total transfers going to non-poor beneficiaries (billion), average transfer per beneficiary (Yuan per year). 


\section{References}

1. Alkire, S., \& Fang, Y. (2019). Dynamics of Multidimensional Poverty and Uni-dimensional Income Poverty: An Evidence of Stability Analysis from China. Social Indicators Research, 142(1), 25-64. https://doi.org/10.1007/s11205-018-1895-2

2. Alkire, S., Shen, Y., Alkire, S., \& Shen, Y. (2017). Exploring Multidimensional Poverty in China: 2010 to 2014. In Research on Economic Inequality: Vol. 25. Research on Economic Inequality (Vol. 25, pp. 161-228). https://doi.org/10.1108/S1049-258520170000025006

3. Cai, Y., \& Xia, C. (2018). Interpretive Structural Analysis of Interrelationships among the Elements of Characteristic Agriculture Development in Chinese Rural Poverty Alleviation. Sustainability, 10(3), 786. https://doi.org/10.3390/su10030786

4. Carrin, G., Ron, A., Hui, Y., Hong, W., Tuohong, Z., Licheng, Z., ... Xuesheng, L. (1999). The reform of the rural cooperative medical system in the People's Republic of China: Interim experience in 14 pilot counties1The present article is largely based on findings and data in Carrin et al. (1996).1. Social Science \& Medicine, 48(7), 961-972. https://doi.org/10.1016/S0277-9536(98)00396-7

5. Central Committee of the Communist Party of China. (2016, December). The 13th FiveYear Plan for Economic and Social Development of the People's Republic of China. Retrieved September 3, 2019, from Green Growth Knowledge Platform website: http://en.ndrc.gov.cn/newsrelease/201612/P020161207645765233498.pdf

6. Chen, J., Dong, H., Yu, H., Gu, Y., \& Zhang, T. (2018). Impact of new rural cooperative medical scheme on the equity of health services in rural China. BMC Health Services Research, 18(1), 486. https://doi.org/10.1186/s12913-018-3288-2 
7. Chen, S., \& Ravallion, M. (1996). Data in transition: Assessing rural living standards in Southern China. China Economic Review, 7(1), 23-56. https://doi.org/10.1016/S1043951X(96)90018-8

8. Cheng, E. (2007). THE DEMAND FOR MICROCREDIT AS A DETERMINANT FOR MICROFINANCE OUTREACH - EVIDENCE FROM CHINA. Savings and Development, 31(3), 307-334. Retrieved from JSTOR.

9. Ding, H., Qin, C., \& Shi, K. (2018). Who benefit from government-led microfinance projects? Evidence from rural China. Journal of Comparative Economics, 46(4), 1253-1272.

10. Duclos, J.-Y., Araar, A., \& Giles, J. (2010). Chronic and transient poverty: Measurement and estimation, with evidence from China. Journal of Development Economics, 91(2), 266277. https://doi.org/10.1016/j.jdeveco.2009.09.002

11. Glauben, T., Herzfeld, T., Rozelle, S., \& Wang, X. (2012). Persistent Poverty in Rural China: Where, Why, and How to Escape? World Development, 40(4), 784-795. https://doi.org/10.1016/j.worlddev.2011.09.023

12. Goh, C., Luo, X., \& Zhu, N. (2009). Income growth, inequality and poverty reduction: A case study of eight provinces in China. China Economic Review, 20(3), 485-496. https://doi.org/10.1016/j.chieco.2008.10.008

13. Golan, J., Sicular, T., \& Umapathi, N. (2017). Unconditional Cash Transfers in China: Who Benefits from the Rural Minimum Living Standard Guarantee (Dibao) Program? World Development, 93, 316-336. https://doi.org/10.1016/j.worlddev.2016.12.011

14. Han, H., \& Gao, Q. (2019). Does Welfare Participation Improve Life Satisfaction? Evidence from Panel Data in Rural China. Journal of Happiness Studies. https://doi.org/10.1007/s10902-019-00157-z 
15. Hannum, E. (2003). Poverty and Basic Education in Rural China: Villages, Households, and Girls' and Boys' Enrollment. Comparative Education Review, 47(2), 141-159. https://doi.org/10.1086/376542

16. Hu, A., Linlin, H., \& Zhixiao, C. (2005). China's Economic Growth and Poverty Reduction (1978-2002). Retrieved September 15, 2019, from /paper/China\%E2\%80\%99s-EconomicGrowth-and-Poverty-Reduction-Angang-Linlin/c883fc7496aa1b920b05dc2546b880f54b9c77a4

17. Hua, X., Yan, J., \& Zhang, Y. (2017). Evaluating the role of livelihood assets in suitable livelihood strategies: Protocol for anti-poverty policy in the Eastern Tibetan Plateau, China. Ecological Indicators, 78, 62-74. https://doi.org/10.1016/j.ecolind.2017.03.009

18. Imai, K. S., \& You, J. (2014). Poverty Dynamics of Households in Rural China (SSRN Scholarly Paper No. ID 2515609). Retrieved from Social Science Research Network website: https://papers.ssrn.com/abstract $=2515609$

19. Jalan, J., \& Ravallion, M. (1998). Transient Poverty in Postreform Rural China. Journal of Comparative Economics, 26(2), 338-357. https://doi.org/10.1006/jcec.1998.1526

20. Jalan, J., \& Ravallion, M. (1999). Are the poor less well insured? Evidence on vulnerability to income risk in rural China. Journal of Development Economics, 58(1), 61-81. https://doi.org/10.1016/S0304-3878(98)00103-5

21. Jalan, J., \& Ravallion, M. (2000). Is transient poverty different? Evidence for rural China. Journal of Development Studies, 36(6), 82-99.

22. Kakwani, N., Li, S., Wang, X., \& Zhu, M. (2019). Evaluating the effectiveness of the rural minimum living standard guarantee (Dibao) program in China. China Economic Review, $53(\mathrm{C}), 1-14$. 
23. Li, X., Gan, C., \& Hu, B. (2011). The welfare impact of microcredit on rural households in China. The Journal of Socio-Economics, 40(4), 404-411. https://doi.org/10.1016/j.socec.2011.04.012

24. Lin, J., Zhang, Z., \& Lv, L. (2019). The Impact of Program Participation on Rural Household Income: Evidence from China's Whole Village Poverty Alleviation Program. Sustainability, 11(6), 1-15.

25. Liu, C., \& Ma, G. (2018). Are Place-Based Policies Always a Blessing? Evidence from China's National Poor County Programme. The Journal of Development Studies, 0(0), 1-13. https://doi.org/10.1080/00220388.2018.1438598

26. Liu, W., Xu, J., Li, J., \& Li, S. (2019). Rural Households' Poverty and Relocation and Settlement: Evidence from Western China. International Journal of Environmental Research and Public Health, 16(14). https://doi.org/10.3390/ijerph16142609

27. Liu, Yanhua, \& Xu, Y. (2016). A geographic identification of multidimensional poverty in rural China under the framework of sustainable livelihoods analysis. Applied Geography, 73, 62-76. https://doi.org/10.1016/j.apgeog.2016.06.004

28. Liu, Yansui, Liu, J., \& Zhou, Y. (2017). Spatio-temporal patterns of rural poverty in China and targeted poverty alleviation strategies. Journal of Rural Studies, 52, 66-75. https://doi.org/10.1016/j.jrurstud.2017.04.002

29. Liu, Yansui, Yuanzhi, G., \& Zhou, Y. (2018). Poverty alleviation in rural China: Policy changes, future challenges and policy implications. China Agricultural Economic Review, 10, 00-00. https://doi.org/10.1108/CAER-10-2017-0192

30. Lo, K., \& Wang, M. (2018). How voluntary is poverty alleviation resettlement in China? Habitat International, 73, 34-42. https://doi.org/10.1016/j.habitatint.2018.01.002 
31. Lo, K., Xue, L., \& Wang, M. (2016). Spatial restructuring through poverty alleviation resettlement in rural China. Journal of Rural Studies, 47, 496-505.

https://doi.org/10.1016/j.jrurstud.2016.06.006

32. Lü, X. (2015). Intergovernmental transfers and local education provision-Evaluating China's 8-7 National Plan for Poverty Reduction. China Economic Review, 33, 200-211. https://doi.org/10.1016/j.chieco.2015.02.001

33. Majendie, A. (2018, December 16). The Next Economic Superpower: China's 40-Year Rise, in Photos. Retrieved August 26, 2019, from Bloomberg website: https://www.bloomberg.com/news/photo-essays/2018-12-17/china-s-four-decade-opening-inpictures

34. Martin, M. F. (1992). Defining China's Rural Population. The China Quarterly, (130), 392401. Retrieved from JSTOR.

35. McCulloch, N., \& Calandrino, M. (2003). Vulnerability and Chronic Poverty in Rural Sichuan. World Development, 31(3), 611-628. https://doi.org/10.1016/S0305$750 \mathrm{X}(02) 00216-4$

36. Meng, L. (2013). Evaluating China's poverty alleviation program: A regression discontinuity approach. Journal of Public Economics, 101, 1-11. https://doi.org/10.1016/j.jpubeco.2013.02.004

37. Montalvo, J. G., \& Ravallion, M. (2010). The pattern of growth and poverty reduction in China. Journal of Comparative Economics, 38(1), 2-16. https://doi.org/10.1016/j.jce.2009.10.005

38. Moreno, E. L. (2017, September 5). Concepts, definitions and data sources for the study of urbanization: The 2030 Agenda for Sustainable Development. Retrieved from 
https://www.un.org/en/development/desa/population/events/pdf/expert/27/papers/II/pap er-Moreno-final.pdf

39. Naminse, E. Y., \& Zhuang, J. (2018). Does farmer entrepreneurship alleviate rural poverty in China? Evidence from Guangxi Province. PLOS ONE, 13(3), e0194912. https://doi.org/10.1371/journal.pone.0194912

40. Park, A., \& Wang, S. (2010). Community-based development and poverty alleviation: An evaluation of China's poor village investment program. Journal of Public Economics, 94(9), 790-799. https://doi.org/10.1016/j.jpubeco.2010.06.005

41. Park, A., Wang, S., \& Wu, G. (2002). Regional poverty targeting in China. Journal of Public Economics, 86(1), 123-153. https://doi.org/10.1016/S0047-2727(01)00108-6

42. Qi, D., \& Wu, Y. (2015). A multidimensional child poverty index in China. Children and Youth Services Review, 57, 159-170. https://doi.org/10.1016/j.childyouth.2015.08.011

43. Ratigan, K. (2017). Disaggregating the Developing Welfare State: Provincial Social Policy Regimes in China. World Development, 98(C), 467-484.

44. Ravallion, M. (2009). Decentralizing Eligibility for a Federal Antipoverty Program. World Bank Economic Review, 23(1), 1-30. https://doi.org/10.1093/wber/lhn023

45. Ravallion, M., \& Chen, S. (2005). Hidden impact? Household saving in response to a poorarea development project. Journal of Public Economics, 89(11), 2183-2204. https://doi.org/10.1016/j.jpubeco.2004.12.003

46. Ravallion, M., \& Jalan, J. (2001). Household Income Dynamics in Rural China (SSRN Scholarly Paper No. ID 632775). Retrieved from Social Science Research Network website: https://papers.ssrn.com/abstract $=632775$ 
47. Ren, Z., Ge, Y., Wang, J., Mao, J., \& Zhang, Q. (2017). Understanding the inconsistent relationships between socioeconomic factors and poverty incidence across contiguous poverty-stricken regions in China: Multilevel modelling. Spatial Statistics, 21, 406-420. https://doi.org/10.1016/j.spasta.2017.02.009

48. Rogers, S. (2014). Betting on the strong: Local government resource allocation in China's poverty counties. Journal of Rural Studies, 36, 197-206. https://doi.org/10.1016/j.jrurstud.2014.08.001

49. Rozelle, S., Park, A., Benziger, V., \& Changqing, R. (1998). Targeted poverty investments and economic growth in China. World Development, 26(12), 2137-2151. https://doi.org/10.1016/S0305-750X(98)00104-1

50. Seth, S. A. and S. (2016). On Relationship between Income Poverty and Multidimensional Poverty in China (No. ophiwp101_1.pdf). Retrieved from Queen Elizabeth House, University of Oxford website: https://ideas.repec.org/p/qeh/ophiwp/ophiwp101_1.pdf.html

51. Shen, Y., Alkire, S., \& Peng, Z. (2019). Measurement and Decomposition of MultiDimensional Poverty in China. China Economist; Beijing, 14(3), 12-28. http://dx.doi.org.ezproxy.library.ubc.ca/10.19602/j.chinaeconomist.2019.5.02

52. South China Morning Post. (2018). Extreme poverty in China: Poorest village hopes for change. Retrieved from https://www.youtube.com/watch?v=W11o_4keAwA

53. Tian, Y., Wang, Z., Zhao, J., Jiang, X., \& Guo, R. (2018). A Geographical Analysis of the Poverty Causes in China's Contiguous Destitute Areas. Sustainability; Basel, 10(6), 1895. http://dx.doi.org.ezproxy.library.ubc.ca/10.3390/su10061895

54. Travers, L., \& Ma, J. (1994). Agricultural productivity and rural poverty in China. China Economic Review, 5(1), 141-159. https://doi.org/10.1016/1043-951X(94)90019-1 
55. Turvey, C. G., \& Kong, R. (2010). Informal lending amongst friends and relatives: Can microcredit compete in rural China? China Economic Review, 21(4), 544-556. https://doi.org/10.1016/j.chieco.2010.05.001

56. Wang, X., Zhou, L., \& Shang, X. (2015). Child Poverty in Rural China: Multidimensional Perspective. Asian Social Work and Policy Review, 9(2), 109-124. https://doi.org/10.1111/aswp.12050

57. Wang, Yanfei, Liu, Y., Li, Y., \& Li, T. (2016). The spatio-temporal patterns of urban-rural development transformation in China since 1990. Habitat International, 53, 178-187. https://doi.org/10.1016/j.habitatint.2015.11.011

58. Wang, Yanhui, \& Wang, B. (2016). Multidimensional poverty measure and analysis: A case study from Hechi City, China. SpringerPlus, 5(1), 642. https://doi.org/10.1186/s40064-016$2192-7$

59. Ward, P. S. (2016). Transient Poverty, Poverty Dynamics, and Vulnerability to Poverty: An Empirical Analysis Using a Balanced Panel from Rural China. World Development, 78, 541-553. https://doi.org/10.1016/j.worlddev.2015.10.022

60. Wescott, B., \& Wang, S. (2019, April 20). Xi Jinping is determined to end all poverty in China by 2020. Can he do it? - CNN. Retrieved September 14, 2019, from CNN website: https://www.cnn.com/2019/04/19/asia/poverty-alleviation-2020-xi-jinping-intl/index.html

61. Wilmsen, B., \& Wang, M. (2015). Voluntary and involuntary resettlement in China: A false dichotomy? Development in Practice, 25(5), 612-627.

https://doi.org/10.1080/09614524.2015.1051947

62. Xue, L., Wang, M. Y., \& Xue, T. (2013). 'Voluntary' Poverty Alleviation Resettlement in China. Development and Change, 44(5), 1159-1180. https://doi.org/10.1111/dech.12054 
63. Yang, X., Gao, J., Zhou, Z., Yan, J., Lai, S., Xu, Y., \& Chen, G. (2016). Assessing the Effects of the New Cooperative Medical Scheme on Alleviating the Health Payment-Induced Poverty in Shaanxi Province, China. PLOS ONE, 11(7), e0157918. https://doi.org/10.1371/journal.pone.0157918

64. You, J. (2014). Risk, under-investment in agricultural assets and dynamic asset poverty in rural China. China Economic Review, 29, 27-45. https://doi.org/10.1016/j.chieco.2014.02.002

65. You, J., \& Annim, S. K. (2013). The Impact of Microcredit on Child Education: QuasiExperimental Evidence from Rural China (SSRN Scholarly Paper No. ID 2256569). Retrieved from Social Science Research Network website: https://papers.ssrn.com/abstract $=2256569$

66. Yu, J. (2013). Multidimensional Poverty in China: Findings Based on the CHNS. Social Indicators Research, 112(2), 315-336. https://doi.org/10.1007/s11205-013-0250-x

67. Zhang, Z., Luo, Y., \& Robinson, D. (2018). Reducing Food Poverty and Vulnerability among the Rural Elderly with Chronic Diseases: The Role of the New Rural Pension Scheme in China. International Journal of Environmental Research and Public Health, 15(6). https://doi.org/10.3390/ijerph15061253

68. Zhu, M., Shuai, C., Wang, X., Leng, Z., \& Zhang, F. (2018). Analysis of China's policy effect on poverty alleviation: Evidence from Chongqing in the Three Gorges Reservoir Region. Quality \& Quantity. https://doi.org/10.1007/s11135-018-0817-3

69. Zuo, C. (Ed.). (2019). The Evolution of China's Poverty Alleviation and Development Policy (2001-2015). Retrieved from https://www.springer.com/gp/book/9789811316890 